BNL-101087-2012-IR

\title{
Thermal Shock-resistant Cement
}

\author{
T. Sugama, T. Pyatina, S. Gill
}

February 2012
Sustainable Energy Technologies Department/Energy Conversion Group Brookhaven National Laboratory

\author{
U.S. Department of Energy \\ DOE office of Energy Efficiency and Renewable Energy
}

Notice: This manuscript has been authored by employees of Brookhaven Science Associates, LLC under Contract No. DE-AC02-98CH10886 with the U.S. Department of Energy. The publisher by accepting the manuscript for publication acknowledges that the United States Government retains a non-exclusive, paid-up, irrevocable, world-wide license to publish or reproduce the published form of this manuscript, or allow others to do so, for United States Government purposes. 


\section{DISCLAIMER}

This report was prepared as an account of work sponsored by an agency of the United States Government. Neither the United States Government nor any agency thereof, nor any of their employees, nor any of their contractors, subcontractors, or their employees, makes any warranty, express or implied, or assumes any legal liability or responsibility for the accuracy, completeness, or any third party's use or the results of such use of any information, apparatus, product, or process disclosed, or represents that its use would not infringe privately owned rights. Reference herein to any specific commercial product, process, or service by trade name, trademark, manufacturer, or otherwise, does not necessarily constitute or imply its endorsement, recommendation, or favoring by the United States Government or any agency thereof or its contractors or subcontractors. The views and opinions of authors expressed herein do not necessarily state or reflect those of the United States Government or any agency thereof. 


\begin{abstract}
We studied the effectiveness of sodium silicate-activated Class F fly ash in improving the thermal shock resistance and in extending the onset of hydration of Secar \#80 refractory cement. When the dry mix cement, consisting of Secar \#80, Class F fly ash, and sodium silicate, came in contact with water, $\mathrm{NaOH}$ derived from the dissolution of sodium silicate preferentially reacted with Class F fly ash, rather than the \#80, to dissociate silicate anions from Class F fly ash. Then, these dissociated silicate ions delayed significantly the hydration of \#80 possessing a rapid setting behavior. We undertook a multiple heating -water cooling quenching-cycle test to evaluate the cement's resistance to thermal shock. In one cycle, we heated the $200^{\circ} \mathrm{C}$-autoclaved cement at $500^{\circ} \mathrm{C}$ for 24 hours, and then the heated cement was rapidly immersed in water at $25^{\circ} \mathrm{C}$. This cycle was repeated five times. The phase composition of the autoclaved \#80/Class $\mathrm{F}$ fly ash blend cements comprised four crystalline hydration products, boehmite, katoite, hydrogrossular, and hydroxysodalite, responsible for strengthening cement. After a test of 5cycle heat-water quenching, we observed three crystalline phase-transformations in this autoclaved cement: boehmite $\rightarrow \gamma-\mathrm{Al}_{2} \mathrm{O}_{3}$, katoite $\rightarrow$ calcite, and hydroxysodalite $\rightarrow$ carbonated sodalite. Among those, the hydroxysodalite $\rightarrow$ carbonated sodalite transformation not only played a pivotal role in densifying the cementitious structure and in sustaining the original compressive strength developed after autoclaving, but also offered an improved resistance of the \#80 cement to thermal shock. In contrast, autoclaved Class G well cement with and without Class F fly ash and quartz flour failed this cycle test, generating multiple cracks in the cement. The major reason for such impairment was the hydration of lime derived from the dehydroxylation of portlandite formed in the autoclaved cement, causing its volume to expand.
\end{abstract}




\section{Introduction}

The major thrust in assembling and constructing Enhanced Geothermal Systems (EGSs) is to create a hydrothermal reservoir in hot dry rock stratum $\geq 200^{\circ} \mathrm{C}$, located at $\sim 3-10 \mathrm{~km}$ below the ground surface. In this operation, water at a low temperature is pumped down from injection well to stimulate the hot rock stratum. This hydraulic stimulation in terms of hydro-shearing initiates the opening of existing fractures. Also, multi-injection wells are required to create a desirable reservoir of a permeable fracture flow network. After forming the reservoir, a production well is installed within the fracture's network.

During the water stimulation cycles, considerable attention is paid to the significant temperature differential between the bottom of the well and the stimulation water from the injection well. This differential suggests that the cement sheath surrounding the down-hole casing may encounter a sudden drop in temperature of $\geq 180^{\circ} \mathrm{C}$. Such a large thermal gradient caused by the cooling effect of the injection water can impact an undesirable thermal stress to the cement sheath, causing its potential failure that may entail the catastrophic failure of the well. To mitigate such stresses due to the temperature differential, the cement placed in EGS must possess the resistances to thermal-cycle fatigue and thermal shock.

As well documented [1-3], when the Ordinal Portland Cement (OPC) is exposed to heating environment at temperatures $\geq 300^{\circ} \mathrm{C}$, the dehydroxylation of portlandite $\left[\mathrm{Ca}(\mathrm{OH})_{2}\right]$ formed in hydrated cements lead to its conversion into lime $(\mathrm{CaO})$. One inevitable concern about the formation of lime is its hydration due to the penetration of water through the set cement. Such insitu portlandite $\rightarrow$ lime $\rightarrow$ hydration phase transformation under a combination of dry and wet conditions is detrimental to the cement's integrity; namely this hydration generates the expansion-caused cracks in the cement body. This undesirable thermal property of OPC containing a certain amount of portlandite can be improved by incorporating quartz (silica flour) into OPC [4-8]. The quartz reacts with portlandite to form additional calcium silicate hydrates, so lowering the amount of portlandite. However, it is very difficult to eliminate all portlandite from OPC-based cement systems in a limited hydration period.

Thus, to develop thermally and hydrothermally stableility cement, we focused on formulating cementitious materials with two specific characteristics: One characteristic is the absence of portlandite formation in hydraulic cement exposed to hydrothermal environments; the other is good refractory properties in thermal environments. There are two candidates for designing the ideal cement encompassing these properties: One candidate is a geopolymer that is prepared by interactions between $\mathrm{Na}$ - or K-based alkaline activators and aluminum silicate-based reactants, such as metakaoline and Class F fly ash. This assembled structure comprises both an amorphousand semi-crystalline zeolitic-phases related to hydroxyl sodalite, Na-PI type, and chabazite [9]. The ceramic-like aluminosilicate network structure in a geopolymer assures its excellent thermal stability [10-12]. However, our study on the compressive strength of the sodium silicateactivated granulated blast-furnace slag/Class F fly ash blend cement systems after autoclaving them at $200^{\circ} \mathrm{C}$ reveals only a minor contribution of geopolymer derived from Class $\mathrm{F}$ fly ash in developing compressive strength in this blended cement [13], although the conversion rate of Class F fly ash into a geopolymer depends on the content of sodium silicate. The major 
contributors to developing strength are the hydrothermal reaction products of slag, suggesting that if the Class F fly ash is employed as a resource in the geopolymer synthesis, we may have to incorporate additional cementitious material into the geopolymer binder to ensure that the cured cement adequately develops a desirable strength under hydrothermal conditions. As this additional cementitious binder, our particular interest lay in using calcium aluminum refractory cement consisting of three major chemical constituents, calcium monoaluminate, calcium dialuminate, and $\alpha$-aluminum oxide because of its great thermal resistance [14-16]. Despite this highly valuable property, its major drawback for subterranean applications is its very fast set that leaves insufficient time for placing the material in a well. Furthermore, combining this material with a low or a high Ca-containing fly ash does not retard its hydration, but, in some cases, accelerate it [17].

Considering all this information, our emphasis in this study is directed toward evaluateding the thermal shock resistance of blended cements consisting of the refractory cement and sodium silicate-activated Class F fly ash, prepared in a hydrothermal environment. For comparison purposes, we evaluated Class $\mathrm{G}$ well cements, unmodified and modified with quartz flour and Class F fly ash, as the controls. The factors to be evaluated included the cement's setting behavior, phase identification and transformation, dehydration and dehydroxylation, and development of microstructure. Thereafter, we integrated all these data, and the integrated information is then correlated directly with the changes in density and compressive strength after thermal shock resistance testing. To conduct an accelerated thermal shock resistance test and to impose considerable thermal stress, we adapted multiple heat-water quenching cycle fatigue procedure under the extremely large temperature differential between heating cement at $500^{\circ} \mathrm{C}$ and water quenching it at $25^{\circ} \mathrm{C}$.

\section{Experimental procedure}

\subsection{Materials}

Class F fly ash was obtained from Boral Material Technologies, Inc., and its chemical composition detected by micro energy-dispersive X-ray spectrometer ( $\mu$ EDX) was as follows; $49.3 \% \mathrm{SiO}_{2}, 36.1 \% \mathrm{Al}_{2} \mathrm{O}_{3}, 5.9 \% \mathrm{Fe}_{2} \mathrm{O}_{3}, 2.3 \% \mathrm{~K}_{2} \mathrm{O}, 2.1 \% \mathrm{MgO}, 1.9 \% \mathrm{CaO}, 1.1 \% \mathrm{TiO}_{2}$, and $1.5 \%$ $\mathrm{Na}_{2} \mathrm{O}$. A sodium silicate granular powder under the trade name "Metos Bead 2048," supplied by the PQ Corporation was used as the alkali activator of Class F fly ash. Its chemical composition was 50.5 mol. wt $\% \mathrm{Na}_{2} \mathrm{O}$ and 46.6 mol. wt\% $\mathrm{SiO}_{2}$. Secar \#80, supplied by Kerneos Inc. was used as calcium aluminate refractory cement. The X-ray powder diffraction (XRD) data showed that the crystalline compounds of Class $\mathrm{F}$ fly ash consisted mainly of three major phases, quartz $\left(\mathrm{SiO}_{2}\right)$, mullite $\left(3 \mathrm{Al}_{2} \mathrm{O}_{3} \cdot 2 \mathrm{SiO}_{2}\right)$, and hematite $\left(\mathrm{Fe}_{2} \mathrm{O}_{3}\right)$, while $\# 80$ included three crystalline phases, corundum $\left(\alpha-\mathrm{Al}_{2} \mathrm{O}_{3}\right)$, calcium monoaluminate $\left(\mathrm{CaO} \cdot \mathrm{Al}_{2} \mathrm{O}_{3}, \mathrm{CA}\right)$, and calcium dialuminate $\left(\mathrm{CaO} .2 \mathrm{Al}_{2} \mathrm{O}_{3}, \mathrm{CA}_{2}\right)$.

The formulas of the dry \#80 and Class F fly ash blend cements had \#80/Class F fly ash ratios of 100/0, 80/20, 60/40, and 40/60 by weight. For Class F fly ash-blended \#80 cements, sodium silicate powder of $6.2 \%$ by the total weight of the blend was added to prepare the one dry mix cement component. No sodium silicate was incorporated into the bulk \#80 cement denoted as the 100/0 \#80/Class F fly ash ratio. The non-blended and blended cement slurries were prepared by adding an appropriate amount of water to the dry mix cement component. The proportion of water to dry cement; the water/cement ratio ranged from 0.42 to 0.47 . After we had thoroughly 
hand-mixed the cement slurries in a bowl for $1 \mathrm{~min}$, samples were cast in cylindrical molds (20 $\mathrm{mm}$ diam. and $40 \mathrm{~mm}$ long), and left to harden for 3 days at room temperature. Then, the hardened cements were autoclaved at $200^{\circ} \mathrm{C}$ for 24 hours. We adapted three formulas for Class $\mathrm{G}$ well cements as the control. One formula was bulk Class $\mathrm{G}$ cement without any additives; the second was $65 \mathrm{wt} \%$ Class G cement and $35 \mathrm{wt} \%$ quartz flour; and the third consisted of $65 \mathrm{wt} \%$ Class $\mathrm{G}$ cement and $35 \mathrm{wt} \%$ Class $\mathrm{F}$ fly ash. The slurries of these cements had water/cement ratios ranging from 0.41 to 0.43 . These slurries then were hardened in the same fashion as that described above.

To obtain information on the thermal shock resistance, a multiple heating -water cooling quenching cycle test was conducted; namely, in the one cycle, the $200^{\circ} \mathrm{C}$-autoclaved cements were placed in an air oven at $500^{\circ} \mathrm{C}$ for 24 hours, and then heated cements were rapidly immersed in water at $25 \mathrm{C}$. This $500^{\circ} \mathrm{C}$ heating $\rightarrow$ water quenching cycle was repeated five times.

\subsection{Measurements}

TAM Air Isothermal Microcalorimetry was used to obtain the initial- and final-setting times and to determine the exothermic hydration heat energy evolved during the curing processes of these slurries at $80^{\circ} \mathrm{C}$. The changes in density and compressive strength of the autoclaved cements after one, three, and five heat-water quenching cycles were measured by helium pycnometry and Forney F-25-Ex Compressive Testing. X-ray powder diffraction (EDX) and Fourier Transform Infrared Spectroscopy (FT-IR) were used to identify the composition of the crystalline phase formed in the autoclaved cements and to define the phase transformations after cycle testing. To support information on the phase transformation due to annealing at $500^{\circ} \mathrm{C}$, we investigated the dehydration- and dehydroxylation-behaviors of hydration reaction products formed in the autoclaved cements using Thermogravimetric Analysis (TGA) at the heating rate of $20^{\circ} \mathrm{C} / \mathrm{min}$ in a $\mathrm{N}_{2}$ flow. The high-resolution scanning electron microscopy (HR-SEM) was used to survey any alternations in the microstructure of cements before and after cycles, and also to explore the morphologies of the crystalline hydrothermal reaction products and dehydrated reaction products. To identify these reaction products, we used energy-dispersive X-ray (EDX) concomitant with HR-SEM.

\section{Results and Discussion}

\subsection{Cement slurry setting tests}

To understand the setting behaviors of Class F fly ash-blended and -non blended \#80 cement slurries at the isothermal temperature of $80^{\circ} \mathrm{C}$, we investigated the following three factors by measuring the heat evolved in neat cement slurries during their hydrolysis and hydration: First, the effect of sodium silicate on activating the pozzolanic-latent Class F fly ash; second, the dissolution of ions from the \#80 cement; and third, the initial- and final-hydration times of the \#80-Class F fly ash blends.

Figure 1 shows the TAM Air micro calorimeter curves in the elapsed times of the first 198 min for 100/0, 80/20, 60/40, and 40/60 \#80/Class F fly ash ratio cement slurries. The bulk \#80 cement without any Class F fly ash set shortly after the ampoule of the cement sample was placed in a calorimeter, so we could not determine the initial setting time and the energy of heat 
evolution. No initial hydration time was identified, or the energy of heat evolution for hydration measured. Two distinctive peaks appeared when the Class F fly ash was incorporated into the \#80 cement; the first peak emerged in the elapsed time ranging from 21 to 91 minutes, while the second one appeared between 54 and 318 minutes. Since the sodium silicate activator dissolves rapidly in the aqueous medium of the slurries the heat of its dissolution is released while the temperature is ramped up to $80^{\circ} \mathrm{C}$ and cannot be analyzed. The first peak denoted as No. 1 seemingly is related to sodium silicate early reactions with the blend components. As is evident from the data listed in Table 1 (the total time elapsed between the peak's onset and its end), the heat flow depended on the ratio of \#80/Class F fly ash. In the slurry made with 80/20 ratio this peak occurred over a total elapsed time of $29 \mathrm{~min}$. The incorporation of more Class F fly ash into the \#80 extended the peak time to 41 and 68 minutes for 60/40 and 40/60 ratios, respectively.

The total energy, $\mathrm{J} / \mathrm{g}$, of heat evolution related to the first peak was computed from the enclosed area of the curve with the baseline made between onset and end times of the peaks. This evolution energy (Table 1) tended to increase with the increase in the Class F and decrease in \#80 contents. In other words, the incorporation of more Class F fly ash into the \#80 cement promoted the reactions of sodium silicate activator. Our preliminary tests with sodium silicate and fly ash $\mathrm{F}$ demonstrated that the hear flow from fly ash and the activator pozzolanic reaction increased with increased sodium silicate concentration (not shown). Since the content of \#80 decreased, it is possible to rationalize that the activator amount involved in reactions with \#80 decreased as well, so that more of it left available for interacting with fly ash $\mathrm{F}$ with the resulting increase in heat flow. To obtain clear information on heat evolution during \#80 cement's hydration, we conducted calorimetric test with this cement at a low temperature of $25^{\circ} \mathrm{C}$. The resulting heat flow-time curve (not shown) revealed two heat peaks: One as the minor peak was a low heat evolution energy detected in the hydration period of time ranging from 63 minutes after the onset to 240 minutes at end; the other as the major peak had a high evolution energy generated between hydration times of 240 and 457 minutes. The former peak was likely due to the release of ionic species such as $\mathrm{Ca}^{2+}$ and $\mathrm{Al}(\mathrm{OH})_{4}{ }^{-}$liberated by hydrolysis of \#80 cement, while the latter was associated with the formation of calcium aluminates.

The peak associated with the release of ionic species by hydrolysis of $\# 80$ at $80^{\circ} \mathrm{C}$ is the second peak marked as No. 2 (Table 1). The data revealed that the heat evolution energy reduced when decreasing the \#80/ Class F fly ash ratio, while an elapsed time to reach the peak was prolonged by increasing the Class F fly ash content. Furthermore, an extremely low energy of $(0.9 \mathrm{~J} / \mathrm{g}) \mathrm{was}$ determined from the 40/60 \#80/Class F fly ash ratio; not only was this due to the reduced content of \#80, but we conjecture that another factor might be involved in preventing ion dissociation from \#80. Although there was no scientific evidence, one possible factor for such prevention might reflect the migration of ionic species dissociated from Class $\mathrm{F}$ fly ash on to the \#80 cements' surfaces after its pozzolanic reaction with $\mathrm{NaOH}$. Nevertheless, incorporating sodium silicate-activated Class F fly ash seems to retard the ionic dissolution and initial hydration of the \#80 cement.

Table 2 lists the initial- and final- hydration times of peaks denoted as No. 3 in Figure 2 for $80 / 20,60 / 40$, and 40/60 ratio slurries. As mentioned earlier, the onset of hydration for 100/0 ratio cement was very difficult to detect because of its rapid setting at $80^{\circ} \mathrm{C}$. However, we observed a final hydration time of $5 \mathrm{~h} 08 \mathrm{~min}$ after placing the sample ampoule into the calorimeter set-up. For 80/20 ratio cement, hydration began after $1 \mathrm{~h} 53 \mathrm{~min}$ and ended at $8 \mathrm{~h} 45 \mathrm{~min}$, suggesting 
that replacing $20 \mathrm{wt} . \%$ of the total amount of the \#80 cement by Class F fly ash definitively retarded the hydration of the \# 80 cement. Further retardation brought about by Class $\mathrm{F}$ fly ash is evident from the 60/40 and 40/60 ratios; in particular, for the latter, the onset of initial hydration was delayed by nearly 26 hours, compared with that of $80 / 20$ ratio. This information undoubtedly verified that sodium silicate-activated Class F fly ash contributed significantly to retarding the hydration of the \#80 cement; such delay might be caused by the ionic species liberated from activated Class F fly ash. On the other hand, as expected, the total energy generated during the hydration of the \#80 depended on its content; namely, this energy declined with the decreasing ratio of the \#80/Class F fly ash, from $167.2 \mathrm{~J} / \mathrm{g}$ for $80 / 20$ ratio to $67.0 \mathrm{~J} / \mathrm{g}$ for $40 / 60$ ratio.

To validate the effect of ionic species dissociated from Class $\mathrm{F}$ fly ash on retarding the hydration of the $\# 80$ cement, we carried out two additional heat flow experiments at $80^{\circ} \mathrm{C}$. In the first calorimetric experiment, we evaluated effect of sodium silicate on \#80 cement hydration. Slurries were prepared from \#80 cement blends with 4, 6, and $8 \mathrm{wt}$. \% of the sodium silicate. These slurries were poured into ampoules and placed in a calorimeter at $80^{\circ} \mathrm{C}$. In the second test, we used the same composition as in 60/40 ratio \#80 cement/Class F fly ash blend with $4 \%$ by weight of blend sodium silicate. However, initially only a dry blend of Class F fly ash and sodium silicate (at $10 \%$ by weight of fly ash $\mathrm{F}$ ) was mixed with water. The obtained slurry was cured at $80^{\circ} \mathrm{C}$ for 24 hours. Then, we extracted the pore solution from the slurry by centrifuging it for 10 minutes at 6,000 rpm. New slurry of \#80 cement was prepared with the extracted pore solution and tested in the calorimeter at $80^{\circ} \mathrm{C}$. Figure 3 shows the heat evolution curves for these four samples. The results demonstrated that incorporating more sodium silicate into the \#80 cement extended the final hydration time of \#80 cement slurries, from $5 \mathrm{~h} 9$ min for $4 \mathrm{wt}$. \% sodium silicate to $10 \mathrm{~h} 26 \mathrm{~min}$ for $8 \mathrm{wt}$. \% sodium silicate, while the heat energies evolved during the hydration of the \#80 cement ranged from $\sim 350$ to $\sim 255 \mathrm{~J} / \mathrm{g}$. Also, there was no hydration peak after 13 hours for the \#80 cement slurry made with pore solution extracted from sodium silicate-treated Class $\mathrm{F}$ fly ash. From this fact, we assumed that silicate anion, $\mathrm{SiO}_{4}{ }^{4-}$, dissociated from Class $\mathrm{F}$ fly ash may play major role in retarding the hydration of the \#80 cement.

\subsection{Thermal Shock Resistance Test}

For these tests, we used the \#80 cement and its blends with Fly Ash Class F, and also we tested Class $\mathrm{G}$ well cement with and without quartz flour or Class F fly ash as controls.

\subsubsection{Density and compressive strength}

Figure 4 reveals the changes in density of the $200^{\circ} \mathrm{C}$-autoclaved cement specimens made with bulk Class G, 65/35 Class G/Class F fly ash and /quartz flour ratio, bulk \#80, and 80/20, 60/40, and $40 / 60$ \#80/Class $\mathrm{F}$ fly ash fly ratios, as a function of $500^{\circ} \mathrm{C}$ heat $-25^{\circ} \mathrm{C}$ water quenching cycle. To support these results, Figure 5 shows the appearance of the cement specimens after cycle tests. The density of bulk Class $\mathrm{G}$ well cement-made specimens sharply dropped to 1.88 $\mathrm{g} / \mathrm{cm}^{3}$ from $2.54 \mathrm{~g} / \mathrm{cm}^{3}$ after only one cycle. Such a drastic reduction of density engendered undesirable alteration in the cement including volumetric expansion that we implicated in multicrack generation, impairing the cement's integrity. The resistance of this Class G cement markedly improved after incorporating Class F fly ash and quartz flour into it. In fact, when 35 wt\% Class $\mathrm{G}$ cement was replaced with Class F fly ash, corresponding to 65/35 Class G/Class F 
fly ash ratio cement, its original density after one cycle decreased only $8 \%$ to $2.18 \mathrm{~g} / \mathrm{cm}^{3}$, and a further extended cycle to 5 times resulted in a $12.2 \%$ reduction. A similar tendency for density to fall with an extending cycle was observed with the $35 \mathrm{wt} \%$ quartz flour-blended Class $\mathrm{G}$ cement; namely, the $2.81 \mathrm{~g} / \mathrm{cm}^{3}$ density of non-cycled cement fell by $18.9 \%$ to $1.89 \mathrm{~g} / \mathrm{cm}^{3}$ after 5 cycles. However, we visually observed the generation of cracks after 3 cycles for these Class $\mathrm{G}$ cements modified with either fly ash F or quartz flour (Figure 6), underscoring that the ability of Class $\mathrm{G}$ cement to resist the thermal shock stress was very poor.

In contrast, the bulk \#80 cement denoted as 100/0 ratio demonstrated that its original density slightly increased with an extending cycle to 3 times, beyond that cycle, it declined. A similar trend was observed with the 80/20 \#80/Class F fly ash ratio. Replacement of the total \#80 cement with Class F fly ash to 40 and $60 \mathrm{wt} \%$ was characterized by an increase in density after one cycle, before it leveled off. This fact strongly demonstrated that adding Class F fly ash improved the resistance of \#80 cements to thermal shock. Nonetheless, the resistance of \#80-based cements to thermal shock appeared to be far greater than that of the Class G-based cements, representing the reliability of \#80 as a refractory cement.

Figure 7 plots the changes in compressive strength as a function of heat-water quenching cycle for the same cement specimens as those used in the density testing. In the Class $\mathrm{G}$ cement series, the $200^{\circ} \mathrm{C}$-autoclaved bulk Class $\mathrm{G}$ cement (100/0 ratio) had a compressive strength of 3175 psi. Its strength fell by $31 \%$ to 2196 psi after one cycle. No further tests were undertaken on it because of its severe disintegration. The compressive strength of autoclaved Class $\mathrm{G}$ cement was improved by replacing $35 \mathrm{wt} \%$ of total Class $\mathrm{G}$ cement with the quartz flour and Class $\mathrm{F}$ fly ash, reflecting an increasing strength by 2.0 - and 1.5- fold, respectively. However, annealing at $500^{\circ} \mathrm{C}$, followed by water quenching, was highly detrimental to these Class $\mathrm{G}$ cements, causing a considerable reduction of strength after 3 cycles to 3805 psi from its original strength of 6193 psi for one with quartz flour, and to 1978 psi from 4610 psi for Class F fly ash. After 5 cycles, we observed severe damage for these specimens, making it more difficult for us to conduct for their strength testing.

In the autoclaved \#80-based cement series, the bulk \#80 cement displayed the highest compressive strength of 6475 psi. However, this strength declined with an increasing replacement of the content of the \#80 cement with Class F fly ash. In fact, the 40/60 \#80/Class F fly ash ratio cement exhibited a compressive strength of 2699 psi, which is 2.4 -fold lower than that of 100/0 ratio. The results from the cycle test revealed that the strength of the cements made with 100/0 and 80/20 ratios decreased with a more cycle. At 5 cycles, the 4325 psi and 3260 psi compressive strengths for 100/0 and 80/20 ratios, respectively, were tantamount to a $33 \%$ and $37 \%$ reduction, compared with that before the test. By comparison, the 60/40 and 40/60 ratio cements exhibited no significant changes in compressive strength after 5 cycles; in particular, the compressive strength of the 5-cycled 60/40 ratio somewhat increased over that of the 3-cycled one. Consequently, sodium silicate-activated Class F fly ash-blended \#80 cements appeared to have potential as alternative thermal shock-resistance cements.

\subsubsection{XRD and FT-IR analyses}

Based upon the information described above, our focus next centered on interpreting comprehensively and obtaining a better understanding of why sodium silicate-activated 60/40 and 40/60 \#80/Class F fly ash ratio cements sustained their compressive strength without any 
generations of cracks during the 5 cycle-water quenching test, compared with the failure of Class $\mathrm{G}$ cements modified and unmodified with Class $\mathrm{F}$ fly ash and quartz flour. To obtain this information, we analyzed these cements by XRD and FT-IR before and after 5 cycles.

Figure 8 reveals the XRD tracings of modified and unmodified Class $\mathrm{G}$ cements after autoclaving at $200^{\circ} \mathrm{C}$. The unmodified bulk Class $\mathrm{G}$ cement (a) included three crystalline hydrothermal reaction products, portlandite $\left[\mathrm{Ca}(\mathrm{OH})_{2}\right]$ as the major phase, and $\alpha$-dicalcium silicate hydrate $\left(\alpha-2 \mathrm{CaO} \cdot \mathrm{SiO}_{2} \cdot \mathrm{H}_{2} \mathrm{O}, \alpha-\mathrm{C}_{2} \mathrm{SH}\right)$ as well as calcium silicate hydrate (1) $\left(\mathrm{CaO} . \mathrm{SiO}_{2} \cdot \mathrm{H}_{2} \mathrm{O}, \mathrm{CSH}\right)$ as minor phases. For the Class $\mathrm{F}$ fly ash-modified Class $\mathrm{G}$ cement (b), the feature of its X-ray pattern was quite different from that of unmodified cement; in particular, two new major hydrothermal reaction products, $1.1 \mathrm{~nm}$ tobermorite, $\left[\mathrm{Ca}_{5}(\mathrm{OH}) \mathrm{SiO}_{6} \mathrm{O}_{16} \cdot 4 \mathrm{H}_{2} \mathrm{O}\right]$ and hydrogrossular $\left[\mathrm{Ca}_{3} \mathrm{Al}_{2} \mathrm{Si}_{2} \mathrm{O}_{8}(\mathrm{OH})_{4}\right]$, were formed, while the portlandite became the minor crystalline phase. Also, the CSH (1) phase was present as one of the major crystalline compounds. Since the Class F fly ash consisted of three crystalline phases, quartz $\left(\mathrm{SiO}_{2}\right)$, mullite $\left(3 \mathrm{Al}_{2} \mathrm{O}_{3} \cdot 2 \mathrm{SiO}_{2}\right)$, and hematite $\left(\mathrm{Fe}_{2} \mathrm{O}_{3}\right)$, it is possible to rationalize that the hydrogrossular was formed by hydrothermal reactions between Class $\mathrm{G}$ cement and mullite in Class $\mathrm{F}$ fly ash; concurrently, the reactions between Class $\mathrm{G}$ cement and quartz in Class F fly ash led to the creation of $1.1 \mathrm{~nm}$ tobermorite and well-formed CSH (1) phases. A similar X-ray pattern, excepting no formation of hydrogrossular, was observed from the quartz flour-modified Class $\mathrm{G}$ cement (c); namely, tobermorite and CSH (1) were the major hydrothermal reaction products. Nevertheless, these crystalline reaction products were responsible for strengthening the $200^{\circ} \mathrm{C}$ autoclaved cements.

As described earlier in this paper, when these autoclaved cements were annealed at $500^{\circ} \mathrm{C}$, followed by water-quenching, all Class $\mathrm{G}$ cement-based specimens generated cracks and fissures in the cement bodies, although the extent of its failure depended on the silica- and silicate-based additives. As illustrated in Figure 9, the XRD result (a) from unmodified Class G cement after 1 cycle showed the presence of calcite $\left(\mathrm{CaCO}_{3}\right)$ and lime $(\mathrm{CaO})$, while the intensity of all portlandite-related $d$-spacing lines was strikingly decayed, suggesting that the dehydroxylation and carbonation of portlandite converted it into lime and calcite. This result agreed with that of previous investigators [1-3]; the formation of lime was detrimental to the cement's integrity because of its hydration and recrystallization to reform portlandite during the water-quenching period, causing an undesirable volumetric expansion of cement. Thus, in the heat-quenching cycles, portlandite first was converted into lime during annealing at $500^{\circ} \mathrm{C}$, and then the hydration of lime after immersion in water engendered the reformulation of crystalline portlandite. This repeated in-situ reversible-phase transformation, $\mathrm{Ca}(\mathrm{OH})_{2} \leftrightarrow \mathrm{CaO}$, drove the volumetric- expansion and -shrinkage of cement, and then promoted the g generation of cracks and fissures, causing the cement to disintegrate.

In contrast, no calcite and lime phases were found in both Class G/Class F fly ash and /quartz flour blend cements after 3 cycles. The XRD pattern (b) of Class G/Class F fly ash cement was characterized by revealing a marked reduction of tobermorite- and CSH (1)-related line intensities and the elimination of hydrogrossular-related $d$-spacing, while some portlandite was presence. Although some tobermorite and CSH (1) phases were reduced by annealing-caused dehydration, we still believed that the generation of cracks in Class F fly ash-modified Class $\mathrm{G}$ cement primarily reflected a reversible portlandite $\leftrightarrow$ lime phase transformation during heatwater quenching tests. A similar X-ray pattern (c) was observed from Class G/ quartz flour blend 
cement, implying that the failure of cement was brought about by the presence of portlandite in cement.

Figure 10 compares the feature of XRD patterns for 100/0 (a), 80/20 (b), 60/40 (c), and 40/60 (d) \#80/ Class $\mathrm{F}$ fly ash ratio cements after $200^{\circ} \mathrm{C}$ autoclaving. The bulk \#80 cement (100/0 ratio) was composed of three crystalline phases, boehmite $(\gamma-\mathrm{AlOOH})$ and Si-free katoite $\left[\mathrm{Ca}_{5} \mathrm{Al}_{2}(\mathrm{OH})_{12}\right]$ belonging to the hydrogarnet family as the major hydrothermal reaction products, coexisting with corumdum $\left(\alpha-\mathrm{Al}_{2} \mathrm{O}_{3}\right)$ as the non-reacted original ingredient present in \#80 cement. Replacing $20 \%$ of the total amount of \#80 cement with Class F fly ash (denoted as $80 / 20$ \#80/Class $\mathrm{F}$ fly ash ratio) led to the incorporation of one additional reaction product, hydroxysodalite $\left[\mathrm{Na}_{4} \mathrm{Al}_{3} \mathrm{Si}_{3} \mathrm{O}_{12}(\mathrm{OH})\right]$ in the family of zeolite, known as hydroceramic $[17,18]$, into the autoclaved cement, while the quartz detected came from the Class F fly ash. Since the hydrolysis of sodium silicate activator in water generated two major reactants, sodium hydroxide and silicic acid, the hydrothermal reactions between sodium hydroxide and mullite $\left(3 \mathrm{Al}_{2} \mathrm{O}_{3} \cdot 2 \mathrm{SiO}_{2}\right)$ in Class $\mathrm{F}$ fly ash led to the formation of hydroxysodalite. Increasing this replacement to $40 \%$, corresponding to 60/40 \#80/Class $\mathrm{F}$ fly ash ratio, generated another new reaction product as an intermediate hydrogrossular $\left[\mathrm{Ca}_{3} \mathrm{Al}_{2} \mathrm{Si}_{2} \mathrm{O}_{8}(\mathrm{OH})_{4}\right]$. Also, this X-ray pattern revealed that the intensity of $d$-spacing lines related to boehmite and katoite phases considerably decayed as more Class F fly ash was added. With 40/60 \#80/Class F fly ash ratio (d), two reaction products, hydroxysodalite and intermediate hydrogrossular, became the major phases; meanwhile it was very difficult to detect the boehmite- and katoite-associated $d$-spacing lines.

To support information on the phase composition of the \#80/Class F fly ash blended and nonblended cements described above, FT-IR analyses were carried out for the same cement as those used in the XRD study, over the frequency range of 4000-650 $\mathrm{cm}^{-1}$ (Figure 11). The FT-IR spectrum of the autoclaved bulk \#80 cement (a) encompassed the seven absorption bands at $3659,3302,3087,1498,1411,1068$, and $729 \mathrm{~cm}^{-1}$. All bands, except for 3659, 1498 and 1411 $\mathrm{cm}^{-1}$, were ascribed to boehmite- and katoite-related groups [19,20]; namely, at 3302 and 3087 $\mathrm{cm}^{-1}$ due to the $\mathrm{O}-\mathrm{H}$ stretching vibrations, at $1068 \mathrm{~cm}^{-1}$ corresponding to Al-O-H bending mode, and at $729 \mathrm{~cm}^{-1}$ associated with the Al-O stretching mode. On the other hand, the band at 3659 $\mathrm{cm}^{-1}$ was an $\mathrm{OH}$ valence-stretching vibration of non-bonded hydroxyl group in water, and two other bands at 1498 and $1422 \mathrm{~cm}^{-1}$ are attributable to the stretching vibration of $\mathrm{CO}_{3}$ in carbonated compounds. With 80/20 \#80/Class F fly ash ratio cement (b), two new additional absorption bands at 1161 and $967 \mathrm{~cm}^{-1}$ were incorporated into the spectrum of bulk \#80 cement. The possible contributor to the former new band was the Si-O asymmetric stretching mode in $\mathrm{Si}$ $\mathrm{O}-\mathrm{Si}$ or -Al linkages [21], and the latter band represents the non oxygen-bridging $\mathrm{Si}^{-\mathrm{O}^{-}}$stretching mode in $\mathrm{Na}^{+}{ }^{-} \mathrm{O}-\mathrm{Si}$ - linkage in hydroxysodalite [22-24]. If this interpretation is correct, increasing the amount of Class F fly ash to 40 (c) and $60 \mathrm{wt} \%$ (d) was responsible for intensifying the absorbance at $967 \mathrm{~cm}^{-1}$ band, emphasizing that these cements included more hydroxysodalite. Meanwhile, the absorbance of boehmite- and katoite-related bands was considerably reduced, reflecting a minimal amount of boehmite and katoite phases.

Relating this information on phase identification to that on the compressive strength of $200^{\circ} \mathrm{C}$ autoclaved cements discussed earlier, the two phases, katoite and boehmite, formed in hydrated \#80 cement, were responsible for the development of the highest compressive strength in \#80/Class F fly ash blend cement series. Since incorporating Class F fly ash into the \#80 cement was reflected in a decrease in compressive strength, the other phases, such as hydroxysodalite 
and intermediate hydrogrossular, derived from Class F fly ash, did not contribute significantly to improving any compressive strength in a hydrothermal environment.

Figure 12 depicts the X-ray patterns of 100/0 (a), 80/20 (b), 60/40 (c), and 40/60 (d) \#80/Class F fly ash ratio cements after 5 cycles. For 100/0 ratio, the particular feature of this pattern was the emergence of two new crystalline compounds, $\gamma-\mathrm{Al}_{2} \mathrm{O}_{3}$ and calcite $\left(\mathrm{CaCO}_{3}\right)$, and the disappearance of all hydration products, such as boehmite and katoite. The $\gamma-\mathrm{Al}_{2} \mathrm{O}_{3}$ phase was formed by the dehydration of boehmite $[25,26]$, and the calcite might have been derived through the dehydration-carbonation process of katoite at $500^{\circ} \mathrm{C}$, while a strong line intensity of the corunmdum-related $d$-spacing still remained unchanged. Relating this finding to the changes in compressive strength, these two different phase transformations, boehmite $\rightarrow \gamma-\mathrm{Al}_{2} \mathrm{O}_{3}$ and katoite $\rightarrow$ calcite, cause a reduction in the compressive strength of the cycled cements. Accordinly, the performance of $\gamma-\mathrm{Al}_{2} \mathrm{O}_{3}$ and calcite phases as cementitious binder in sustaining compressive strength was relatively poor. With 80/20 \#80/Class $\mathrm{F}$ fly ash ratio, the XRD result highlighted the presence of sodium carbonate sodalite $\left(\mathrm{Na}_{8} \mathrm{Al}_{6} \mathrm{Si}_{6} \mathrm{O}_{24} \mathrm{CO}_{3}\right)$ phase in terms of carbonated sodalite as a new carbonation product coexisting with calcite and $\gamma-\mathrm{Al}_{2} \mathrm{O}_{3}$. The carbonation of hydroxysodalite expressed as the phase transformation, $\mathrm{Na}_{4} \mathrm{Al}_{3} \mathrm{Si}_{3} \mathrm{O}_{12}(\mathrm{OH}) \rightarrow$ $\mathrm{Na}_{8} \mathrm{Al}_{6} \mathrm{Si}_{6} \mathrm{O}_{24} \mathrm{CO}_{3}$, let to the intercalating $\mathrm{CO}_{3}$ into sodalite structure by the replacement of the $\mathrm{OH}$ group in sodalite with $\mathrm{CO}_{3}$. Thus, the hydroxysodalite possessed a specific property associated with the sequestration of $\mathrm{CO}_{2}$, implying that the sodalite-based cementitious materials could be categorized as $\mathrm{CO}_{2}$-resistant cement. The X-ray pattern of 5-cycled 60/40 ratio cement expressed three major characteristics: First, the intermediate hydrogrossular phase formed in this cement's autoclaving was eliminated; second, the intensity of the carbonated sodalite-related lines was enhanced conspicuously, reflecting the incorporation of more carbonated sodalite into the cement bodies; and third was the reduction of the line intensities for the calcite and $\gamma-\mathrm{Al}_{2} \mathrm{O}_{3}$ phases. Relating the second and third characterizations to the compressive strength results, the carbonated sodalite displayed a far greater performance as a cementitious binder in developing compressive strength, compared with that of the calcite and $\gamma-\mathrm{Al}_{2} \mathrm{O}_{3}$ formations. In fact, more carbonated sodalite into the cement bodies in conjunction with a minimized amount of calcite and $\gamma-\mathrm{Al}_{2} \mathrm{O}_{3}$ was responsible for maintaining the value of the compressive strength developed during autoclaving this cement. With 40/60 ratio, the feature of its XRD pattern closely resembled that of cement with a 60/40 ratio.

Figure 13 compares the FT-IR spectral features for the same 5-cycled cements as those used in the XRD study. The spectrum (a) of 5-cycled bulk \#80 cement had two predictable features: One was the elimination of all boehmite- and katoite-related major bands at 3302, 3087, 1068, and $729 \mathrm{~cm}^{-1}$; the other was the presence of strong bands at 1498 and $1415 \mathrm{~cm}^{-1}$ related to $\mathrm{CO}_{3}$ in the calcite, while the band at $3660 \mathrm{~cm}^{-1}$ came from the free water. The spectrum (b) of cycled $80 / 20$ ratio encompassed four bands at 1498, 1415, 1173, and $945 \mathrm{~cm}^{-1}$. The first two bands corresponded to $\mathrm{CO}_{3}$ in the carbonated sodalite and calcite. The second two were attributed to carbonated sodalite; the former band reflects the $\mathrm{Si}-\mathrm{O}$ asymmetric stretching mode in the $\mathrm{Si}-\mathrm{O}-\mathrm{Si}$ or -Al linkages, while the latter was related to the $\mathrm{Si}-\mathrm{O}$ stretching in $\mathrm{Na}^{+}{ }^{-} \mathrm{O}$-Si linkage.

Consequently, compared with a poor performance of calcite and $\gamma-\mathrm{Al}_{2} \mathrm{O}_{3}$ phases formed in cycled \#80 in sustaining the compressive strength, the carbonated sodalite phase derived from the carbonation of Class F fly ash-derived hydroxysodalite phase played a key role in retaining its compressive strength in a heat-water quenching test with $\mathrm{CO}_{2}$. These findings clearly 
demonstrating that the carbonated sodalite phase conferred an excellent resistance to thermal shock on the \#80/Class F fly ash blend cements.

\subsubsection{TGA analysis}

We attempted to obtain information on the effects of dehydration as means of removing water from the interlayer in hydration reaction compounds, and of the dehydroxylation in terms of eliminating the hydroxyl group from hydrated compounds in the $200^{\circ} \mathrm{C}$-autoclaved Class $\mathrm{G}$ well cement- and \#80/Class F fly ash blend-based cements. TGA analyses for these cements were conducted at temperature ranging from $25^{\circ} \mathrm{C}$ to $599^{\circ} \mathrm{C}$. Figure 14 illustrates the TGA curves for bulk Class $\mathrm{G}$ well cement, and 65/35 Class $\mathrm{G}$ well cement/Class F fly ash and /quartz flour ratio cements. For bulk Class $\mathrm{G}$ well cement, the TGA curve exhibited three stages of thermal decomposition: The first stage began at an onset temperature near $75^{\circ} \mathrm{C}$ and ends around $150^{\circ} \mathrm{C}$; the second occurred between $\sim 150^{\circ} \mathrm{C}$ and $\sim 325^{\circ} \mathrm{C}$; and, the third from $\sim 325^{\circ} \mathrm{C}$ to $\sim 475^{\circ} \mathrm{C}$. The first decomposition stage, corresponding to $\sim 1.47 \%$, was due to the elimination of pore free water from cement, and the second stage might signal the dehydration of calcium silicate hydrate (1) [27], while the third stage representing a large weight loss of $\sim 6.44 \%$ involved both the dehydroxylation of portlandite and dehydration of $\alpha$-dicalcium silicate hydrate, which was converted into non-hydrous $\beta$-dicalcium silicate at $800^{\circ} \mathrm{C}$ [28]. By comparison with the feature of this TGA curve, the Class F fly ash-incorporated Class $\mathrm{G}$ cement did not show any pronounced weight loss in this temperature range, although there was a progressive loss in weight. As described earlier in the XRD study, this cement had four major hydration products, $1.1 \mathrm{~nm}$ tobermorite, calcium silicate hydrate (1), portlandite, and hydrogrossular. According to the literatures [29-31], the dehydration of tobermorite and dehydroxylation of hydrogrossular was observed at the temperatures between $50^{\circ}$ and $700^{\circ} \mathrm{C}$ and between $260^{\circ}$ and $350^{\circ} \mathrm{C}$, respectively. Thus, the fact that hydrogrossular disappeared after 3 cycles was likely to demonstrate the possibility of the phase transformation of hydrogrossular into unknown chemical compounds by its dehydroxylation. This TGA data also verified that only minor amount of portlandite underwent dehydroxylation between $\sim 325^{\circ} \mathrm{C}$ and $\sim 475^{\circ} \mathrm{C}$. Correspondingly, the total weight loss at $599^{\circ} \mathrm{C}$ was $10.6 \%$, which was $\sim 20 \%$ lower than that of bulk Class $\mathrm{G}$ cement at the same temperature. Similar feature in the curve and changes in weight loss were evident in the quartz flour-incorporated Class $\mathrm{G}$ well cement, implying that two crystalline phases, $1.1 \mathrm{~nm}$ tobermorite and calcium silicate hydrate (1), have good thermal stability withstanding thermal shock fatigue up to $599^{\circ} \mathrm{C}$. However, although only little portlandite formed in the Class $\mathrm{G}$ cement body during an extended heat-quenching test, its transformation into lime, followed by lime $\rightarrow$ portlandite recrystallization, was a major reason for generation of cracks, and a major drawback of this cement.

Figure 15 compares the feature of TGA curves of 100/0, 80/20, 60/40, and 40/60 \#80/Class F fly ash ratio cements after autoclaving at $200^{\circ} \mathrm{C}$. The $100 / 0$ ratio cement exhibited two decomposition stages: In the first stage, the onset and end temperatures were $\sim 190^{\circ} \mathrm{C}$ and $\sim$ $340^{\circ} \mathrm{C}$, reflecting $\sim 8.46 \mathrm{wt} \%$ loss; second stage was defined to occur between $\sim 400^{\circ} \mathrm{C}$ and $\sim 570^{\circ} \mathrm{C}$, relating to $\sim 5.62 \mathrm{wt} \%$ loss. Since two major hydrothermal reaction products, boehmite and katoite, were formed in this cement, there were two different dehydroxylation processes: The first stage involved katoite [32] that yielded calcite as its carbonation by-product, and second one was due to boehmite $[33,34]$, which converted into $\gamma-\mathrm{Al}_{2} \mathrm{O}_{3}$ as its thermal decomposition product; this conversion lead to a total loss weight of $16.1 \%$ at $599^{\circ} \mathrm{C}$. This loss was 
significantly reduced by adding Class F fly ash to \#80 cement because less of the katoite and boehmite phases were generated. With 80/20 ratio cement, the hydrosodalite as additional hydration reaction product was incorporated into the \#80-based cement. Since hydrosodalite was dehydroxlated at temperatures up to $\sim 350^{\circ} \mathrm{C}$ [35], the weight loss of this cement between $190^{\circ} \mathrm{C}$ and $\sim 350^{\circ} \mathrm{C}$ seemingly involved the dehydroxlations of both the katoite and hydrosodalite. More importantly, the latter was converted into carbonated sodalite during the quenching test, emphasizing that such hydrosodalite $\rightarrow$ carbonated sodalite phase transition might have minimized the total weight loss of cement. Since the 60/40 and 40/60 ratio cements containing more Class F fly ash assemble the hydrosodalite-rich cementitious structure, their weight loss at $599^{\circ} \mathrm{C}$ depended on the content of Class F fly ash; namely, the lowest weight loss of $7.1 \%$ was obtained from the 40/60 ratio cement containing the highest content of Class F fly ash in this test series.

From this overall information detailed above, we identified carbonated sodalite as the most effective phase in improving thermal shock resistance of cements.

\subsubsection{Microstructure Development}

To support these data, we explored the alterations in microstructure developed in the $200^{\circ} \mathrm{C}$ autoclaved Class G, \#80, and 60/40 \#80/Class F fly ash ratio cements after cycle testing by HRSEM and EDX. Figure 16 shows the SEM image coupled with EDX elemental analysis for the autoclaved Class $\mathrm{G}$ well cement. We observed two differential microstructure images, marked as area No. 1 and 2. The EDX at the area No.1 had three major elements, $\mathrm{Ca}, \mathrm{Si}$, and O, suggesting that the microstructure developed in this area was associated with calcium silicate hydrates. In the area No. 2, we noted a lamellate microstructure of plate-like crystals containing $\mathrm{Ca}$ and $\mathrm{O}$ as the major elements, representing the formation of portlandite [36]. Compared to this microstructure, a quite different microstructure can be seen in the same cement after a one-cycle water quenching test (Figure 17); in particular, the appearance of cluster of the grown portlandite crystals in the area No.3, while, in area No.4, a porous microstructure had developed brought about by the dehydration of calcium silicate hydrates. In the former case, the growth of portlandite crystals might be due to the hydration- recrystallization of lime formed by $500^{\circ} \mathrm{C}$ dehydroxylation of the original portlandite crystal during water quenching.

Figure 18 gives the SEM image coupled with EDX analysis of the autoclaved bulk \#80 cement. From two dominated elements, $\mathrm{Al}$ and $\mathrm{O}$, in the rectangular prism crystals that were apparent in No.5 area, we believed that this crystal was attributed to boehmite [37]. The other area, No.6, was likely to be associated with calcium aluminate hydrates encompassing three main elements, $\mathrm{Al}, \mathrm{O}$, and $\mathrm{Ca}$, detected form DEX. In contrast, this cement after 5 cycles expressed a dense microstructure (Figure 19). EDX data taken at two different locations, No. 7 and 8, were very similar, with a strong signal of the $\mathrm{Al}$ and $\mathrm{O}$ elements related to aluminum oxide. Thus, in this \#80 refractory cement, the aluminum oxide compounds yielded during 5-cycle water quenching testing contributed to the development of a dense microstructure, verifying the reliability of this refractory cement at a high thermal temperature.

Figure 20 shows the SEM-EDX findings from autoclaved 60/40 \#80/Class F fly ash ratio cement. In this SEM image, Class F fly ash was identical as microsphere with $\sim 10 \mu \mathrm{m}$ diameter as No. 9. As described under experimental procedures, Class $\mathrm{F}$ fly ash included eight oxide compounds, such as $\mathrm{SiO}_{2}, \mathrm{Al}_{2} \mathrm{O}_{3}$. $\mathrm{Fe}_{2} \mathrm{O}_{3}, \mathrm{~K} 2 \mathrm{O}, \mathrm{MgO}, \mathrm{CaO}, \mathrm{TiO}_{2}$, and $\mathrm{Na}_{2} \mathrm{O}$. Hence, all elements, 
except for some $\mathrm{Ca}, \mathrm{Al}$, and $\mathrm{Si}$ elements belonging to \#80, detected in EDX were assignable to the Class F fly ash. The cementitious structure in the No.10 area without any Class F fly ash microspheres was constituted by calcium aluminate silicate hydrates because of the presence of a prominent $\mathrm{Ca}, \mathrm{Si}, \mathrm{Al}$, and $\mathrm{O}$ signals in the EDX. We observed a dramatic alteration in this cement's microstructure after the 5-cycle thermal shock resistance test (Figure 21). As evident, its microstructure was characterized by two specific morphological features: One was the interactions of Class F fly ash with other cementitious binder, thereby forming a rim structure as the reaction products around spherical fly ash; the other was the development of a very dense microstructure, strongly demonstrating that this microstructure generated by autoclaving was converted into a densified structure during the heat-water quenching cycles.

\section{Conclusion}

We formulated the dry mix cement consisting of three starting materials, Secar \#80 refractory cement, Class F fly ash, and sodium silicate, to evaluate its potential as thermal shock resistant cement for using in EGS injection wells. When this dry mix cement came in contact with water, the sodium silicate dissolved in a cement slurry preferentially reacted with Class F fly ash between the elapsed times of $21 \mathrm{~min}$ at the onset of reaction and $91 \mathrm{~min}$ as its end point at isothermal temperature of $80^{\circ} \mathrm{C}$; this led to the dissociation of silicate anion from Class $\mathrm{F}$ fly ash. This dissociated silicate anion, in turn, significantly delayed the hydration of the \#80 cement. Conceivably, such retardation might be due to the migration of dissociated silicate to the \#80 cements' surfaces. Correspondingly, incorporating more Class F fly ash into the \#80 cement further extended its hydration time. In fact, it was very difficult to determine the initial hydration time of the $\# 80$ cement within the first 30 min because of its rapid setting at $80^{\circ} \mathrm{C}$. When a $40 \mathrm{wt} \%$ of the total amount of the \#80 cement was replaced by Class F fly ash, the initial hydration of \#80 occurred $~ 3 \mathrm{hr}$ later. Replacing 60wt\% with Class F fly ash considerably prolonged this hydration time to $\sim 28 \mathrm{hr}$, corresponding to the extension of nearly 9-fold longer than the $40 \mathrm{wt} \%$ replacement. This finding clearly demonstrated that the setting time of calcium aluminate-based refractory cement can be controlled by varying the content of sodium silicateactivated Class F fly ash in geothermal wells at an elevated temperature.

For comparison with \#80/Class F fly ash blend cement, we employed the Class $\mathrm{G}$ well cement unmodified and modified with Class F fly ash and quartz flour. After autoclaving them at $200^{\circ} \mathrm{C}$, the unmodified Class $\mathrm{G}$ well cement formed three hydrothermal reaction products, the portlandite as the major crystal phase, and $\alpha$-dicalcium silicate and calcium silicate hydrate (l) as the minor crystal phases. Incorporating the Class F fly ash and quartz flour into Class G cement significantly reduced the formation of portlandite. With Class F fly ash, the composition of hydration-related crystalline phase comprised the $1.1 \mathrm{~nm}$ tobermorite, calcium silicate hydrate (1), hydrogrossular, and portlandite. The similar phase composition, except for the absent of hydrogrossular, was observed from quartz flour-modified Class $\mathrm{G}$ cement. To evaluate the resistance to thermal shock for these autoclaved Class $\mathrm{G}$ cements, we adapted an extremely large temperature differential between $500^{\circ} \mathrm{C}$ annealing and $25^{\circ} \mathrm{C}$ water-quenching to accelerate any thermal shock failure of the cements. This annealing-water cooling quenching cycle was repeated five times. The integrity of unmodified Class $\mathrm{G}$ cement was greatly impaired after only one cycle; the major reason for failure was due to the hydration of lime formed by the dehydroxylation of portlandite at $500^{\circ} \mathrm{C}$, generating the volume expansion-caused cracks in cement. Although the thermal shock resistance of Class $\mathrm{G}$ well cement was improved by adding 
Class F fly ash and quartz flour, the presence of portlandite still was detrimental to its integrity; namely, portlandite $\rightarrow$ lime $\rightarrow$ reformulated portlandite occurred as the phase transformation during annealing-water quenching period. Meanwhile, $1.1 \mathrm{~nm}$ tobermorite and calcium silicate hydrate (1) underwent dehydration, while the hydrogrossular in the family of hydrogarnet formed in autoclaved Class G/Class F fly ash system disappeared in this accelerated thermal shock cycle test.

For \#80/Class F fly ash blend cement system, we evaluated the following four formulas, 100/0, $80 / 20,60 / 40$, and 40/60 \#80/Class $\mathrm{F}$ fly ash ratios in thermal shock cycling. The $200^{\circ} \mathrm{C}-$ autoclaved bulk \#80 cement had two major crystalline hydration products, the boehmite and katoite phases. Adding $20 \mathrm{wt} \%$ Class F fly ash to the \#80 cement as 80/20 ratio led to the incorporation of one additional hydrothermal reaction product, the hydroxysodalite, known as hydroceramic. Adding more Class F fly ash resulted in the incorporation of another reaction product, the intermediate hydrogrossular. After a 5-cycle test, two new crystalline phases in the bulk \#80 cement were identified: One was $\gamma-\mathrm{Al}_{2} \mathrm{O}_{3}$; the other was calcite, meanwhile the boehmite and katotite phases formed in the autoclaved \#80 cement were eliminated. Thus, the boehmite was transformed to $\gamma-\mathrm{Al}_{2} \mathrm{O}_{3}$ by its dehydroxylation, $\gamma-\mathrm{AlOOH} \rightarrow \gamma-\mathrm{Al}_{2} \mathrm{O}_{3}$, and the katoite in the family of hydrogarnet was carbonated to form calcite, $\mathrm{Ca}_{3} \mathrm{Al}_{2}(\mathrm{OH})_{12} \rightarrow \mathrm{CaCO}_{3}$. Despite these phase transformation, the \#80 cement did not show any signs of failure such as the generation of cracks, denoting its reliability as refractory cement. However, the original compressive strength developed in the autoclaved cement fell by $33 \%$ to 4325 psi after 5 cycles. For the cement made with 80/20\#80/Class F fly ash ratio, the hydrosodalite formed in autoclaved this cement was transformed to the carbonated sodalite by its carbonation, representative of the replacement of $\mathrm{OH}$ group in hydrosodalite with $\mathrm{CO}_{3}, \mathrm{Na}_{4} \mathrm{Al}_{3} \mathrm{Si}_{3} \mathrm{O}_{12}(\mathrm{OH}) \rightarrow \mathrm{Na}_{8} \mathrm{Al}_{6} \mathrm{Si}_{6} \mathrm{O}_{24} \mathrm{CO}_{3}$, while some $\gamma-\mathrm{Al}_{2} \mathrm{O}_{3}$ and calcite coexisted with carbonated sodalite. With 60/40 and 40/60 ratios, their phase composition closely resembled that of 80/20 ratio. Only one differential was the fact that, like the Class F fly ash-modified Class G cement, the intermediate hydrogrossular produced in autoclaved these ratios disappeared after 5 cycles. Nevertheless, we found that $\mathrm{Na}_{4} \mathrm{Al}_{3} \mathrm{Si}_{3} \mathrm{O}_{12}(\mathrm{OH}) \rightarrow \mathrm{Na}_{8} \mathrm{Al}_{6} \mathrm{Si}_{6} \mathrm{O}_{24} \mathrm{CO}_{3}$ phase transformation not only played a pivotal role in sustaining the compressive strength of cement during annealing-water quenching cycles test, but also contributed significantly to improving further the thermal shock resistance of \#80 cement. In fact, no changes in compressive strength after 5 cycles were observed from the cements made with 60/40 and 40/60 ratios, compared with that of the same cements that had been autoclaved. Thus, among the three crystalline phases, $\gamma-\mathrm{Al}_{2} \mathrm{O}_{3}$, calcite, and carbonated sodalite, assembled in the \#80/Class $\mathrm{F}$ blend cements during cycle testing, the carbonated sodalite not only improves the thermal shock resistance of \#80 refractory cement, but also, it was primarily responsible for densifying the cementitious structure. In addition, such a $\mathrm{CO}_{2}$-sequestaring property of hydrosodalite suggested that this cement could be categorized as $\mathrm{CO}_{2}$-resistant cement.

Consequently, the sodium silicate-containing \#80/Class F fly ash blend cement has good potential as alternative thermal shock resistant cement in EGS wells. 


\section{References}

1. J. Piasta, Heat deformation of cement pastes phases and the mcicrostructure of cement paste, Mater. Struct. 17 (1984) 415-420.

2. P. Kittl, G. Diaz, and H. Alarcon, Dosification of a cement-talk-chamotte refractory mortar subjected to thermal shock, Cem. Concr. Res., 22 (1992) 736742.

3. W.M. Lin, T.D. Lin, and L.J. Power, Microstructure of fire-demaged concrete, ACI Mater. J. 93 (1996) 199-205.

4. R. Siauciunas and A. Baltusnikas, Influence of $\mathrm{SiO}_{2}$ modification on hydrogarnets formation during hydrothermal synthesis, Cem. Concr. Res., 33 (2003) 17891793.

5. k. Luke, Phase studies of pozzolanic stabilized calcium silicate hydrates at $180^{\circ} \mathrm{C}$, Cem. Concr. Res., 34 (2004) 1725-1732.

6. S. Aydin and B. Baradan, Effect of pumice and fly ash incorporation on high temperature resistance of cement based mortars, Cem. Concr. Res., 37 (2007) 988-995.

7. M.S. Morsy and S.S. Shebl, Effect of silica fume and metakaoline pozzolana on the performance of blended cement pastes, Cerm. Silikaty, 51 (2007) 40-44.

8. A.M. Rashad and S.R. Zeedan, A preliminary study of blended pastes of cement and quartz powder under the effect of elevated temperature, Constr. Build. Mater., 29 (2012) 672-681.

9. T. Badharev, Thermal behavior of geopolymers prepared using class $\mathrm{F}$ fly ash and elevated temperature curing, Cem. Concr. Res., 36 (2006) 1134-1147.

10. G.N. Rao and A.N. Kotasthane, Thermal and hydrothermal stabilities of zeolite EU-1, Appl. Cataly. A: General 119 (1994) 33-43.

11. P. Duxson, J.L. Provis, G.C. Lukey, J.S.J. van Deventer, The role of inorganic polymer technology in the development of green concrete, Cem. Concr. Res., 37 (2007) 1590-1597.

12. P.N. Lemongna, K.J.D. McKenzie, and U.F. Chinje Melo, Synthesis and thermal properties of inorganic polymers (geopolymers) for structural and refractory application from volcanic ash, Ceram. Inter., 37 (2011) 3011-3018.

13. T. Sugama, T. Butcher, L. Brother, and D. Bour, Temporary cementitious sealing materials, Geothermal Resources Council (GRC) Transactions, 35 (2011) 247253. 
14. S.M. Bushnell-Watson and J.H. Sharp, Further studies of the effect of temperature upon the setting behavior of refractory calcium aluminate cements, Cem. Concr.

Res., 20 (1990) 623-635.

15. N. Ulkrainczyk and T. Matusinovic, Thermal properties of hydrating calcium aluminate cement pastes, Cem. Concr. Res., 40 (2010) 128-136.

16. S. Martinovic, M. Dojcinovic, M. Dimitrijevic, A. Devecerski, B. Matovic, and T. Volkov Husovic, J. Euro. Ceram. Soc., 30 (2010) 3303-3309.

17. A. Palomo, M.T. Blanco-Varela, M.L. Granizo, F. Puertas, T. Vazquez, and M.W. Grutzeck, Chemical stability of cementitious materials based on metakaolin, Cem. Concr. Res., 29 (1999) 997-1004.

18. S. Chen, M. Wu, and S. Zhang, Mineral phases and properties of alkali-activated metakaolin-slag hydroceramic for a disposal of simulated highly-alkaline wastes, J. Nucl. Mater., 402 (2010) 173-178.

19. D. Mishra, S. Amand, R.K. Panda, and R.P. Das, Hydrothermal preparation and characterization of boehmites, Mater. Lett., 42 (2000) 38-45.

20. S. Fujita, K. Suzuki, and Y. Shibasaki, The mild hydrothermal synthesis of hydrogrossular from coal ash, J. Mater. Cycles Waste Manag., 4 (2002) 41-45.

21. B.N. Roy, Spectroscopic analysis of the structure of silicate glasses along the joint of $\mathrm{xMAlO}_{2}-(1-\mathrm{x}) \mathrm{SiO}_{2}(\mathrm{M}=\mathrm{Li}, \mathrm{Na}, \mathrm{K}, \mathrm{Rb}, \mathrm{Cs})$, J. Am. Ceram. Soc., 70 (1987) $183-$ 192.

22. T. Bakharev, Geopolymeric materials prepared using Class F fly ash and elevated temperature curing, Cem. Concr. Res., 35 (2005) 1224-1232.

23. T. Uchino, T. Sakka and M. Iwasaki, Interpretation of hydrated states of sodium silicate glasses by infrared and raman analysis, J. Am. Ceram. Soc., 74 (1991) 306-313.

24. W.K.W. Lee and J.S.J. Van Deventer, Chemical interaction between siliceous aggregate and low-Ca alkli-activated cements, Cem. Conre. Res., 37 (2007) 844855 .

25. J.-M. Hao, Relationship between the dehydration temperature of boehmite and the imperfection structure of $\gamma$-alumina, Polyhedron, 15 (1996) 2421-2424.

26. H.-L. Wen and F.-S. Yen, Growth characteristics of boehmite-derived ultrafine theta and alpha-alumina particles during phase transformation, J. Cryst. Growth, 208 (2000) 696-708.

27. C.A. Rios, C.D. Williams, and M.A. Fullen, Hydrothermal synthesis of hydrogarnet and tobermorite at $175^{\circ} \mathrm{C}$ from kaolinite and metakaolinite in the $\mathrm{CaO}-\mathrm{Al}_{2} \mathrm{O}_{3}-\mathrm{SiO}_{2}-\mathrm{H}_{2} \mathrm{O}$ system: A comparative study, Appl. Clay Sci. 43 (2009) 228-237. 
28. S. Goni, A. Guerrero, M.P. de Luxan, and A. Macias, Dehydration of pozzolanic products hydrothermally synthesized from fly ash: microstructure evolution, Mater. Res. Bull.,35 (2000) 1333-1344.

29. D.S. Klimesch and A. Ray, DTA-TGA evaluation of the $\mathrm{CaO}-\mathrm{Al}_{2} \mathrm{O}_{3}-\mathrm{SiO}_{2}-\mathrm{H}_{2} \mathrm{O}$ system treated hydrothermally, Thermochim. Acta, 334 (1999) 115-122.

30. S. Shaw, C.M.B. Henderson and B.U. Komanschek, Dehydration/recrystallization mechanisms, energetic, and kinetics of hydrated calcium silicate minerals: an in situ TGA/DSC and synchrotron radiation SAXS/WAXS study, Chem. Geology, 167 (2000) 141-159.

31. A. Gmira, R. J.-M. Pellenq, I. Rannou, L. Duclaux, C. Clinard, T. Cacciaguerra, N. Lequeux and H. Van Damme, A structural study of dehydration/rehydration of tobermorite, a model cement compound, in Studies in Surface and Catalysis 144, F. Rodriguez-Reinoso, B. McEnancy, J. Rouqerol and K. Unger [Eds], Elsevier Science B.V. (2002) 601-608.

32. J.M. Rivas-Mercury, P. Pena, A.H. de Aza, and X. Turrillas, Dehydration of $\mathrm{Ca}_{3} \mathrm{Al}_{2}\left(\mathrm{SiO}_{4}\right)_{\mathrm{y}}(\mathrm{OH})_{4(3-\mathrm{y})}(0<\mathrm{y}<0.176)$ studies by neutron thermodiffractometry, J. Euro. Ceram. Soc., 28 (2008) 1737-1748.

33. B. Xu and P. Smith, Dehydration kinetics of boehmite in the temperature range 723-873 K, Themochim. Acta, 531 (2012) 46-53.

34. P.P. Nampi, S. Ghosh, and K.G. Warrier, Calcination and associated structure modification in boehmite and their influence on high temperature densification of alumina, Ceram. International. 37 (2011) 3329-3334.

35. J. Yao, H. Wang, K.R. Ratinac, and S.P. Ringer, Formation of colloidal hydroxylsodalite nanocrystals by the direct transformation of silicalite nanocrystals, Chem. Mater., 18 (2006) 1394-1396.

36. C. Rodriguez-Navarro, E. Hansen, and W.S. Ginell, Calcium Hydroxide Crystal Evolution upon Aging of Lime Putty, J. Am. Ceram. Soc., 81 (1998) 3032-3034.

37. B. Xu and P. Smith, Dehydration kinetics of boehmite in the temperature range 723-873 K, Thermochim. Acta, 531 (2012) 46-53. 
Table 1. Onset- and ending- times of two heat evolution-related peaks and their total evolution energies for 80/20, 60/40, and 40/60 \#80/Class F fly ash ratio slurries.

\begin{tabular}{|c|c|c|c|c|c|c|}
\hline $\begin{array}{c}\text { \#80/Class F } \\
\text { fly ash ratio }\end{array}$ & \multicolumn{3}{|c|}{ Peak 1 } & \multicolumn{3}{c|}{ Peak 2 } \\
\cline { 2 - 7 } & Onset, & End, & $\begin{array}{c}\text { Heat } \\
\text { evolution, } \\
\text { hr:min }\end{array}$ & $\begin{array}{c}\text { Onset, } \\
\text { hr:min }\end{array}$ & $\begin{array}{c}\text { End, } \\
\text { hr:min }\end{array}$ & $\begin{array}{c}\text { Heat } \\
\text { evolution, } \\
\text { J/g }\end{array}$ \\
\hline $80 / 20$ & $0: 21$ & $0: 50$ & 6.4 & $0: 54$ & $1: 47$ & 3.5 \\
\hline $60 / 40$ & $0: 21$ & $1: 02$ & 13.7 & $1: 05$ & $2: 38$ & 3.1 \\
\hline $40 / 60$ & $0: 23$ & $1: 31$ & 23.8 & $1: 44$ & $5: 18$ & 0.9 \\
\hline
\end{tabular}

Table 2. Initial- and final-hydration times linked to the hydration heating energy for 100/0, $80 / 20,60 / 40$, and $40 / 60 \# 80 / C$ lass $\mathrm{F}$ fly ash ratio slurries at $80^{\circ} \mathrm{C}$.

\begin{tabular}{|c|c|c|c|}
\hline $\begin{array}{c}\text { \#80/Class F fly ash } \\
\text { ratio }\end{array}$ & $\begin{array}{c}\text { Initial hydration } \\
\text { time, hr:min }\end{array}$ & $\begin{array}{c}\text { Final hydration } \\
\text { time, hr:min }\end{array}$ & Hydration heat, J/g \\
\hline $100 / 0$ & Unknown & $5: 08$ & 167.2 \\
\hline $80 / 20$ & $1: 53$ & $8: 45$ & 98.8 \\
\hline $60 / 40$ & $2: 55$ & $21: 56$ & 67.0 \\
\hline $40 / 60$ & $27: 53$ & $148: 08$ & \\
\hline
\end{tabular}




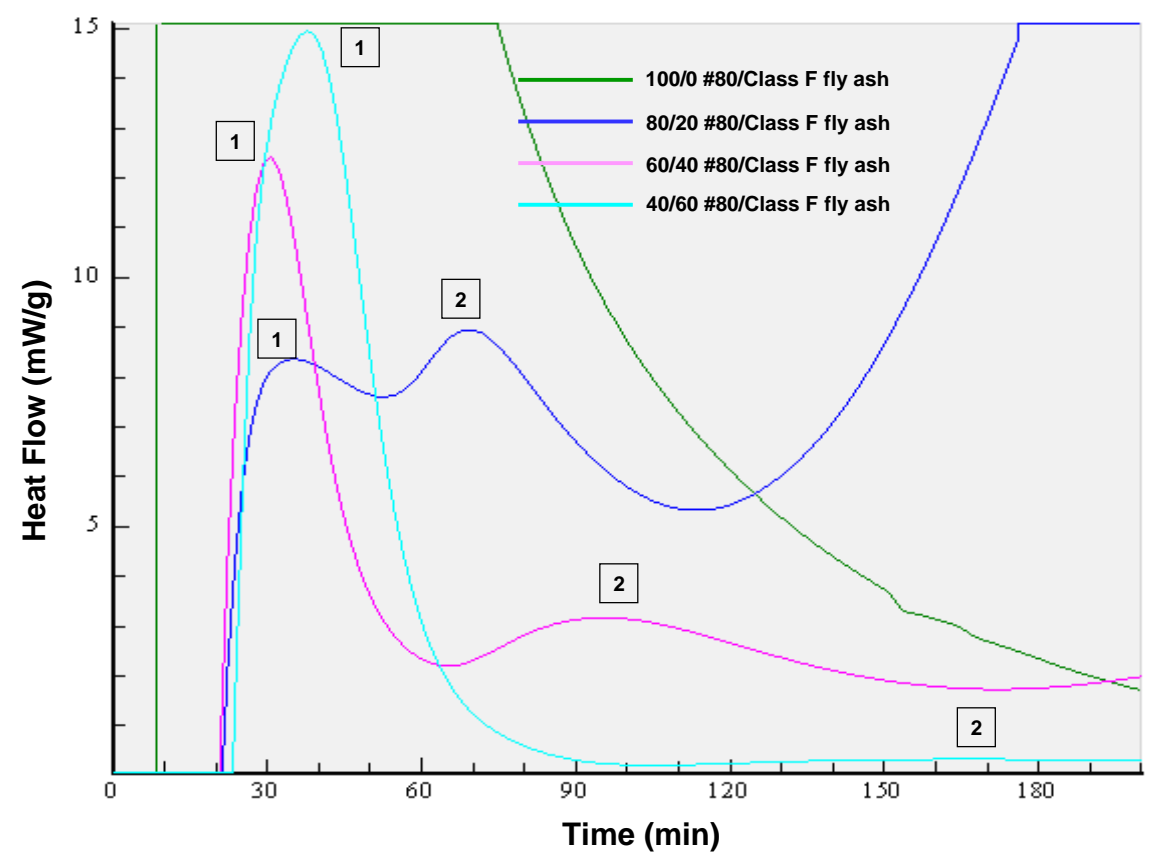

Figure 1. Two heat evolutions generated in the first $198 \mathrm{~min}$ for 80/20, 60/40, and 40/60 \#80/Class F fly ash ratio cement slurries at an isothermal temperature of $80^{\circ} \mathrm{C}$. 


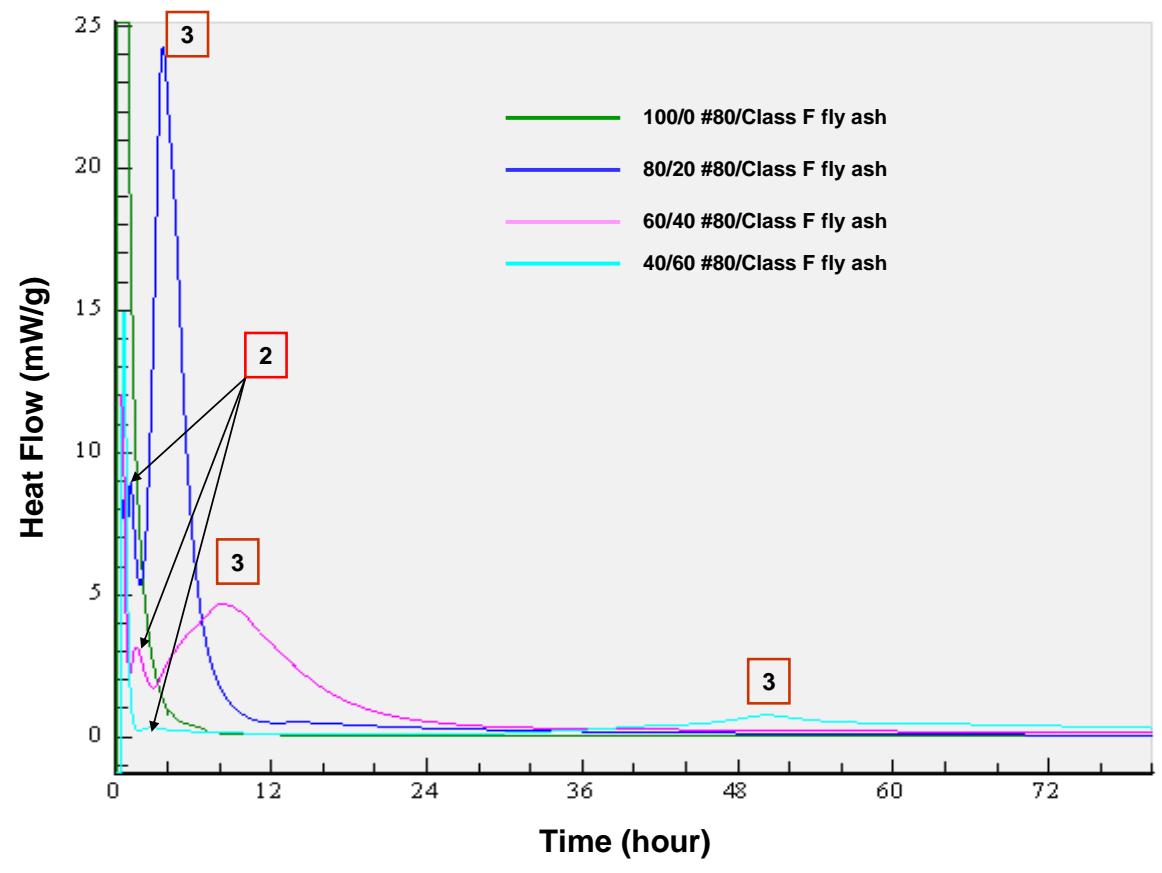

Figure 2. Microcalorimetric curves including the heat of hydration for $100 / 0,80 / 20$, $60 / 40$, and 40/60 \#80/Class F fly ash ratio cement slurries at $80^{\circ} \mathrm{C}$. 


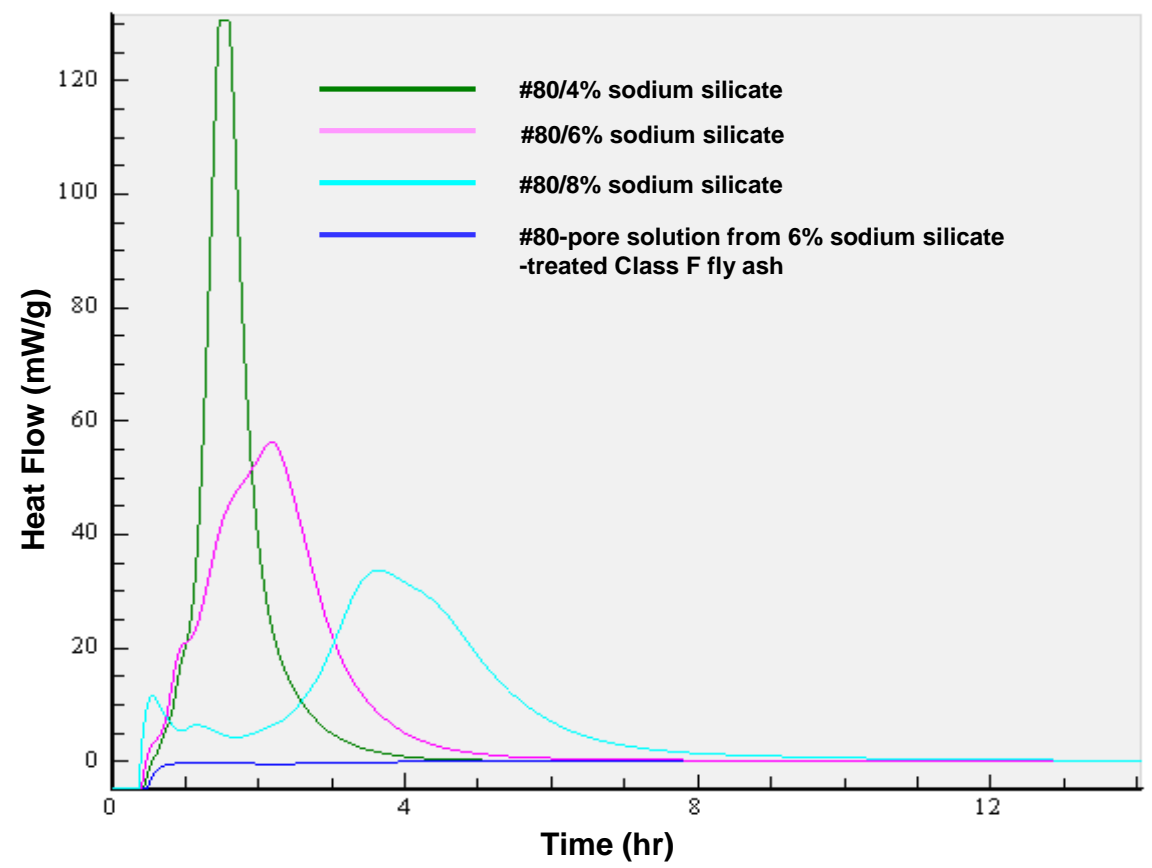

Figure 3. Comparison of hydration curves for $\# 80$ cement slurries treated with 4,6 , and 8 wt $\%$ sodium silicate, and \#80 cement modified with pore solution extracted from $6 \mathrm{wt} \%$ sodium silicate-treated Class F fly ash. 


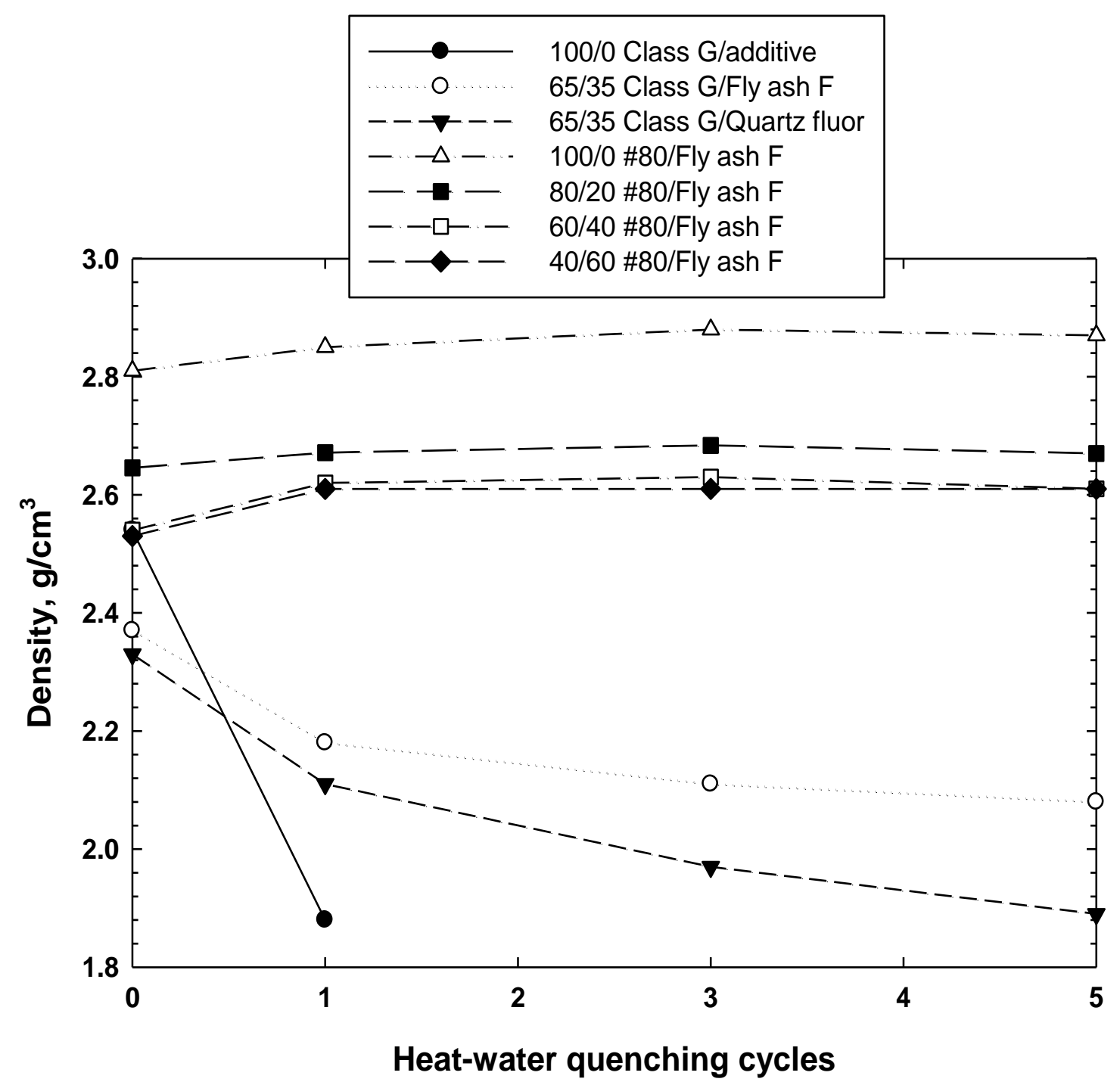

Figure 4. Changes in density of $200^{\circ} \mathrm{C}$-autoclaved cements as a function of $500^{\circ} \mathrm{C}$ annealingwater quenching cycle. 


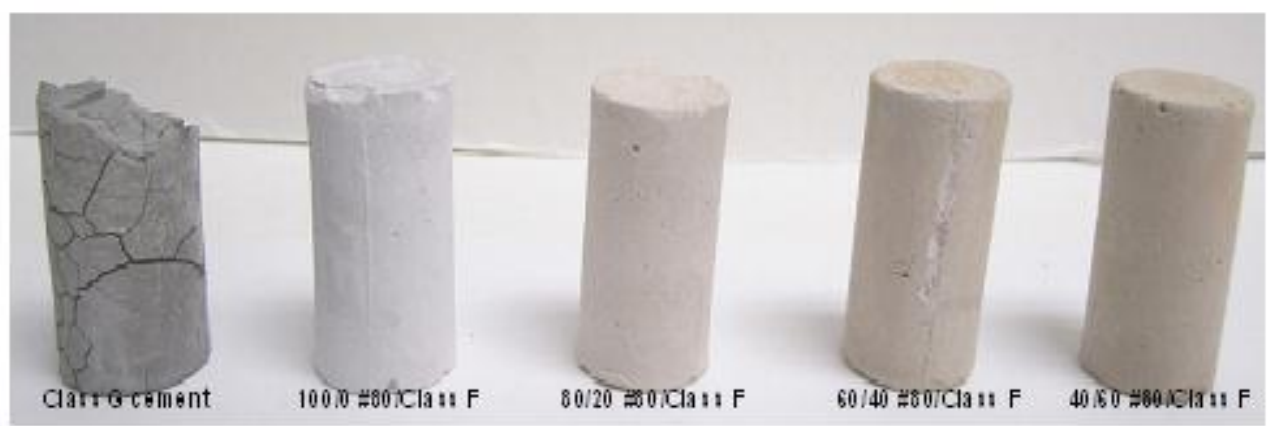

Figure 5. Appearance of Class G cement (after 1 cycle), and 100/0, 80/20, 60/40, and 40/60 \#80/Class F fly ash ratio cements (after 5 cycles) after thermal shock resistance testing .

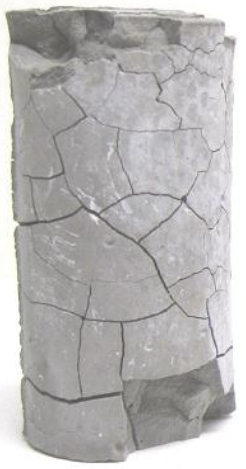

Class $\mathrm{G}$ cement $(\mathrm{G})$ after 1 cycle

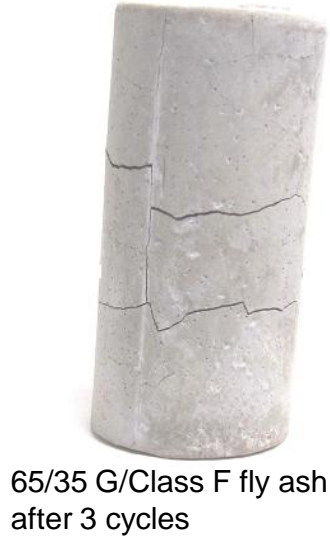

after 3 cycles

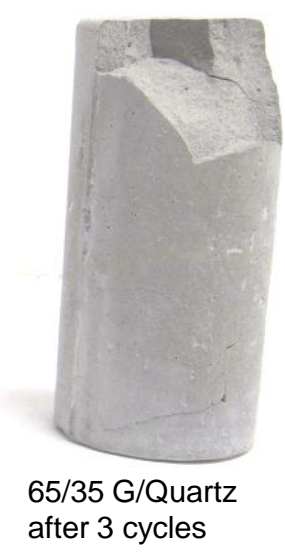

Figure 6. Appearance of Class G well cements unmodified and modified with Class F fly ash and quartz flour after cycle testing up to 3 times. 


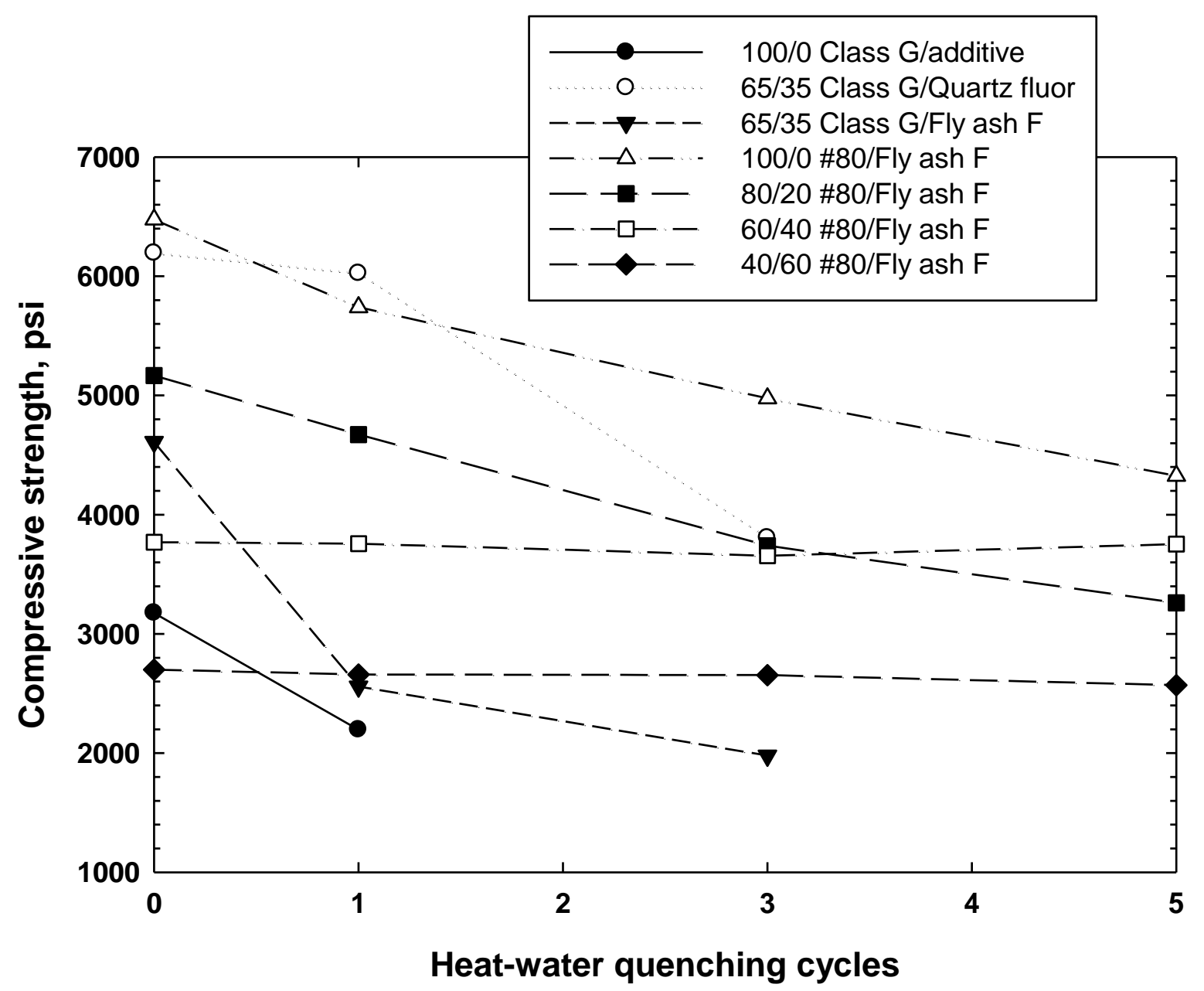

Figure 7. Changes in compressive strength of various different cements as a function of heatwater quenching cycle. 


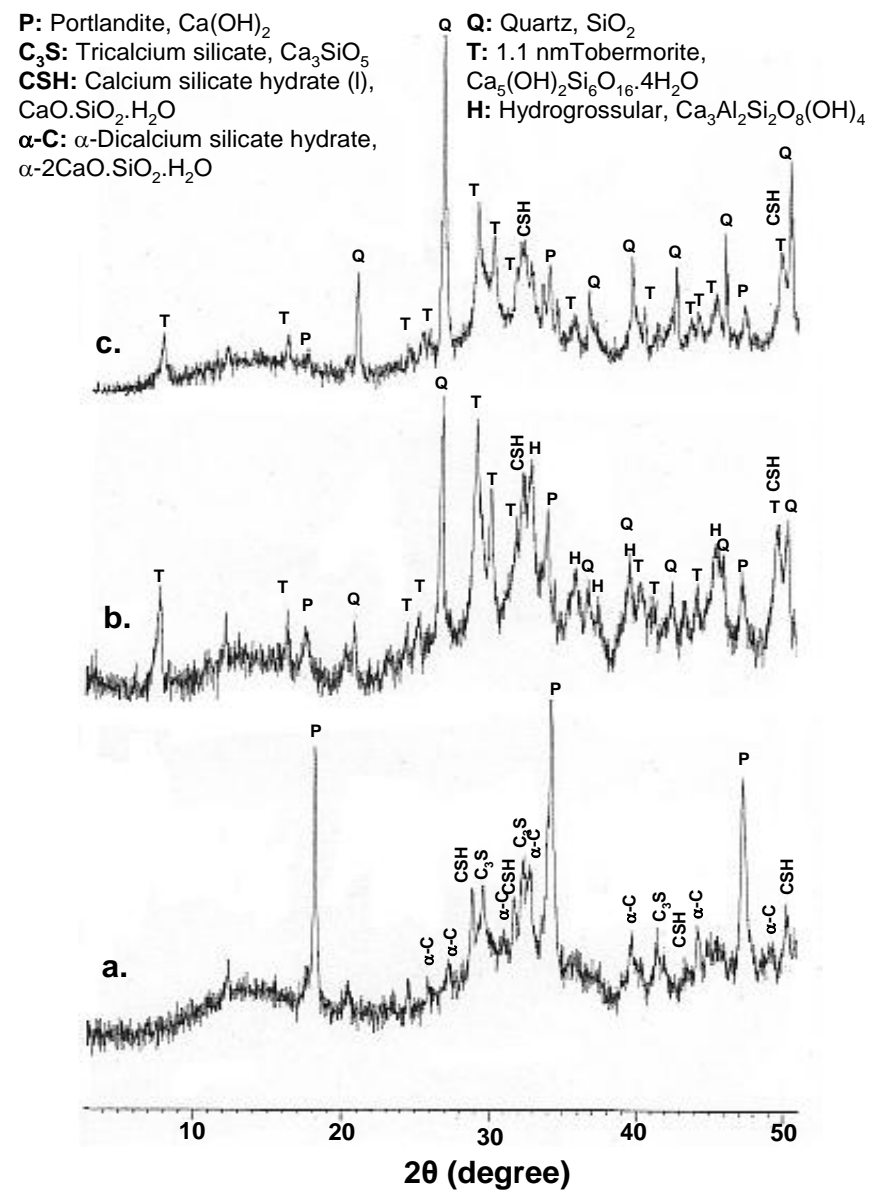

Figure 8. XRD patterns of the Class G cement (a), 65/35 Class G/Class F fly ash ratio cement (b), and 65/35 Class G/quarzt flour ratio cement (c) after autoclaving at $200^{\circ} \mathrm{C}$. 


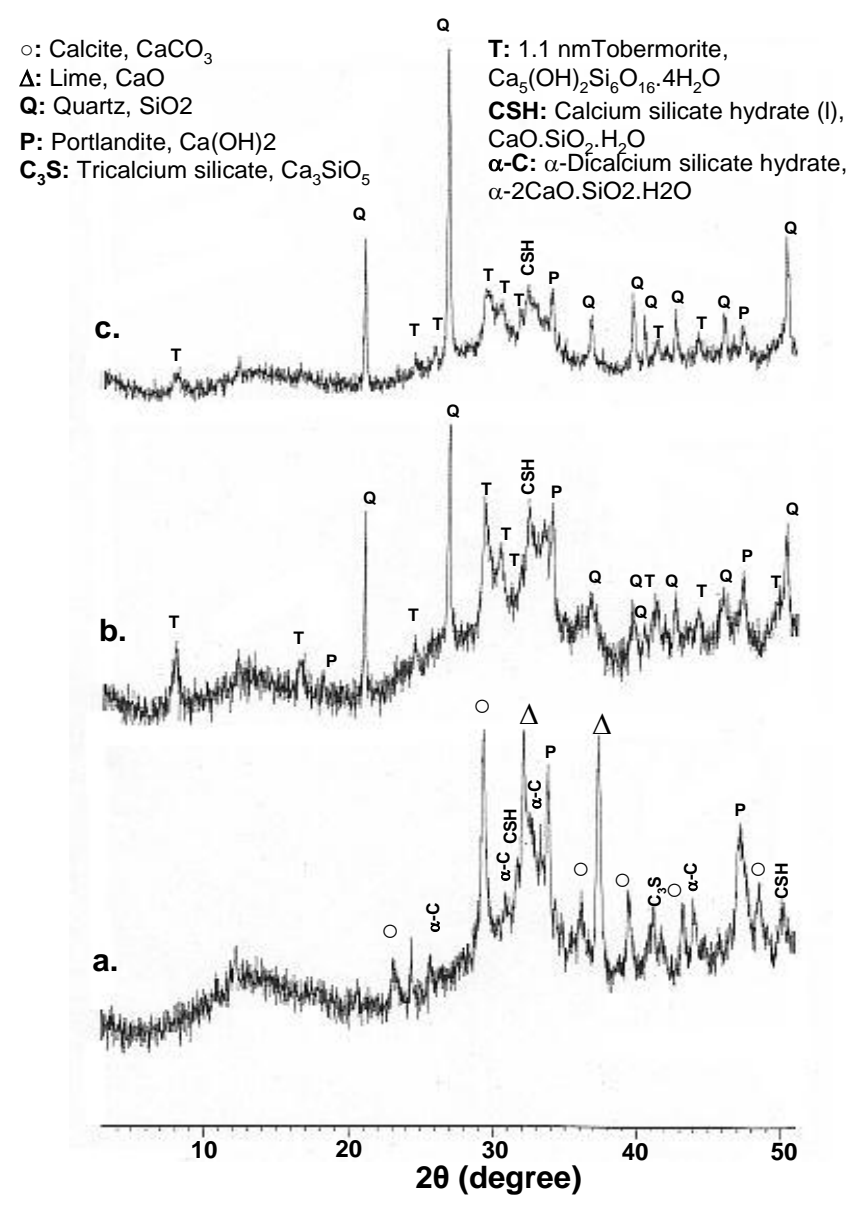

Figrue 9. XRD tracings for Class G cement (a) after 1 cycle, and 65/35 Class G/Class F fly ash ratio cement (b), and 65/35 Class G/quartz flour ratio cement (c) after 3 cycles heat-water quenching test. 


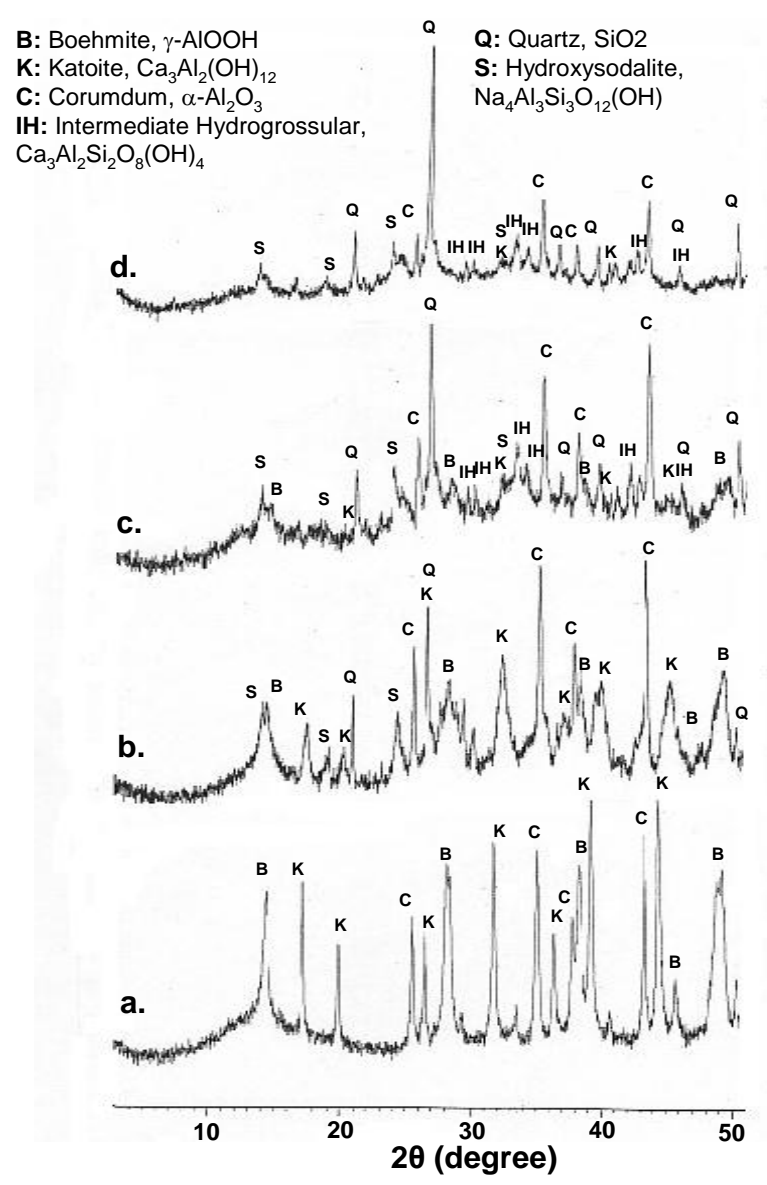

Figure 10. XRD analyses for 100/0 (a), 80/20 (b), 60/40 (c), and 40/60 (d) \#80/Class F fly ash ratio cements after autoclaving at $200^{\circ} \mathrm{C}$. 


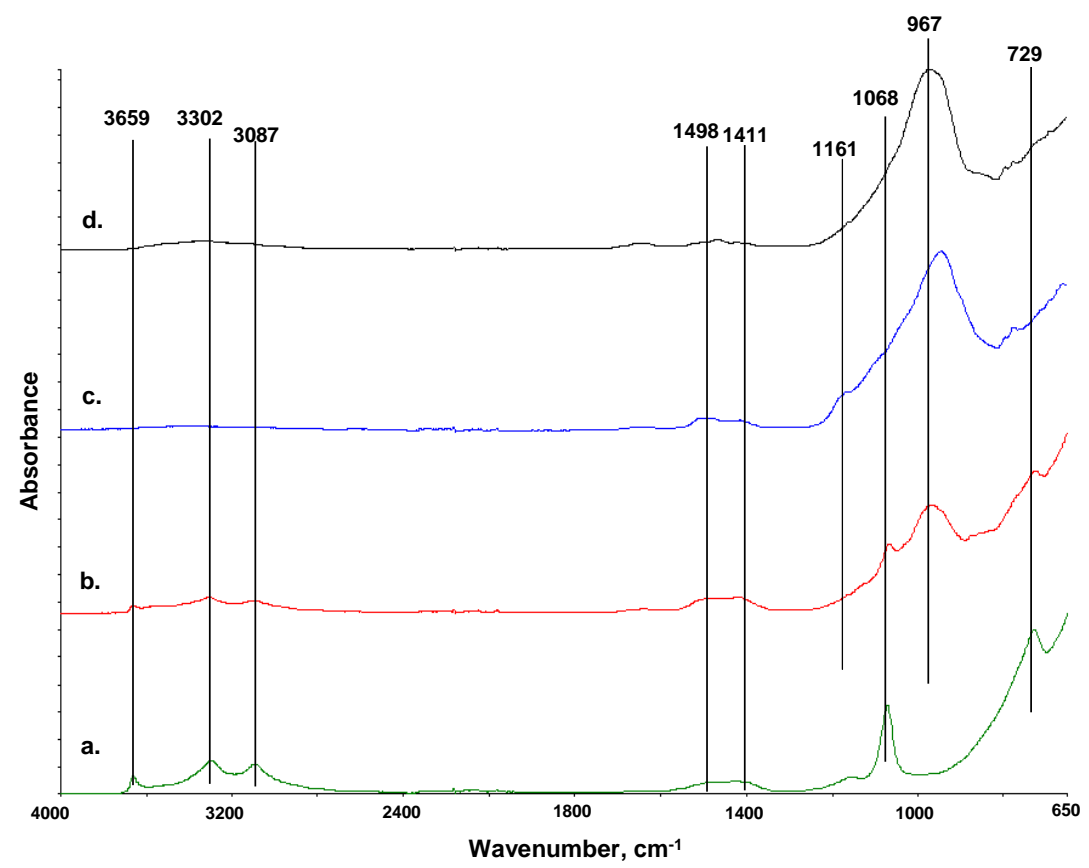

Figure 11. FT-IR spectra of the 100/0 (a), 80/20 (b), 60/40 (c), and 40/60 (d) \#80/Class F fly ash ratio cements after $200^{\circ} \mathrm{C}$ autoclaving. 


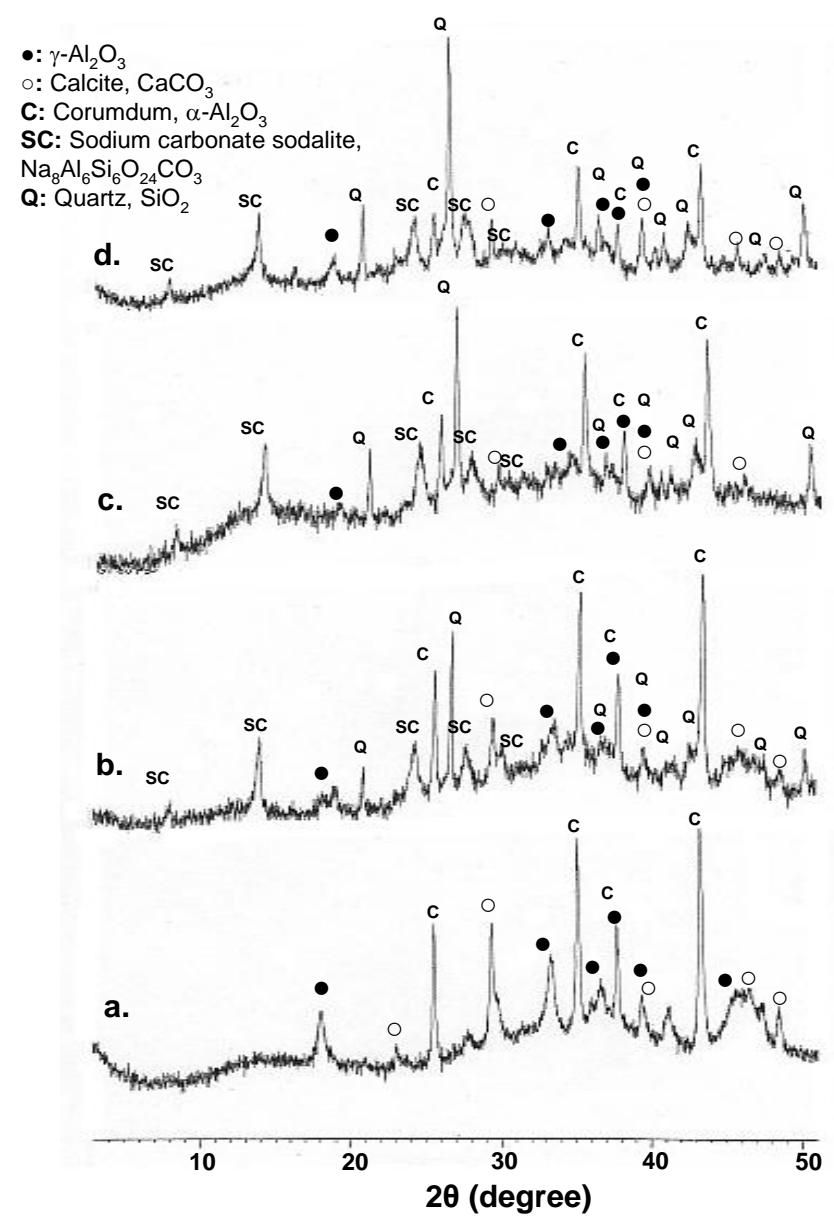

Figure 12. XRD patterns of the 100/0 (a), 80/20 (b), 60/40 (c), and 40/60 (d) \#80/Class F fly ash ratio cements after 5-cycles heat-water quenching test. 


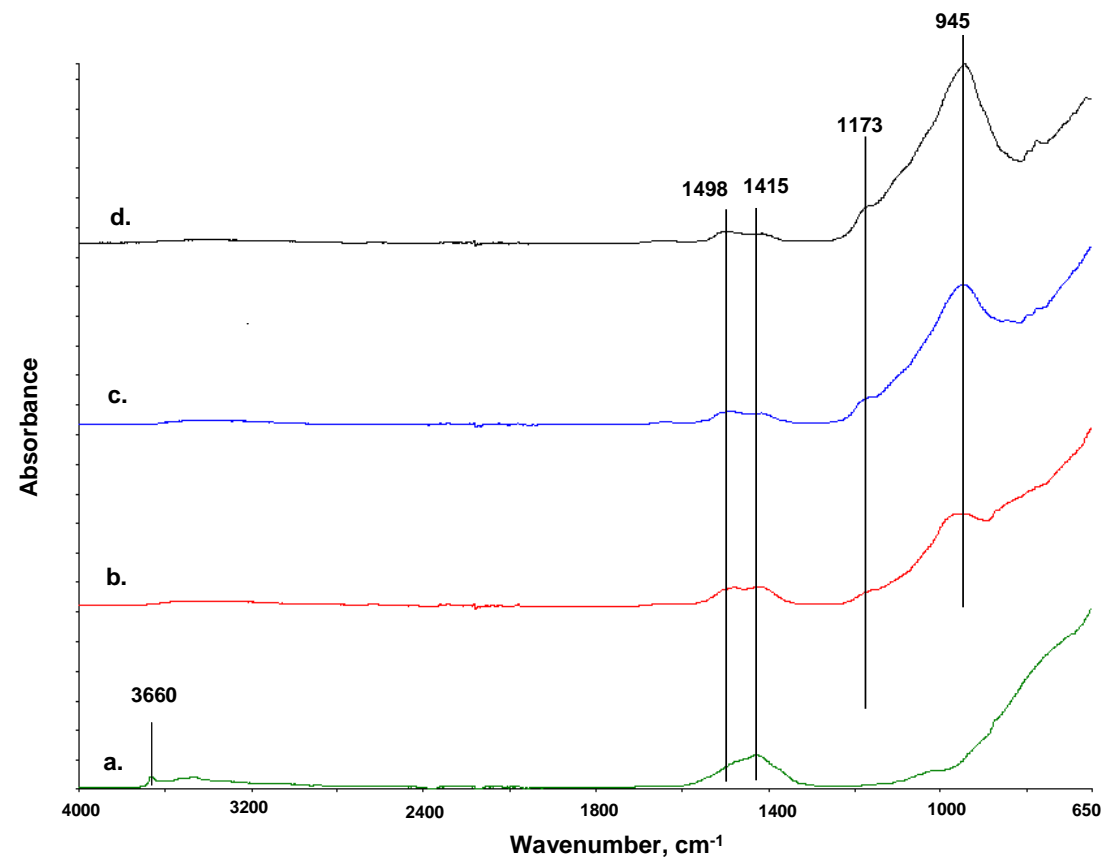

Figure 13. FT-IR analyses for 100/0 (a), 80/20 (b), 60/40 (c), and 40/60 (d) \#80/Class F fly ash ratio cements after 5-cycle heat-water quenching test. 


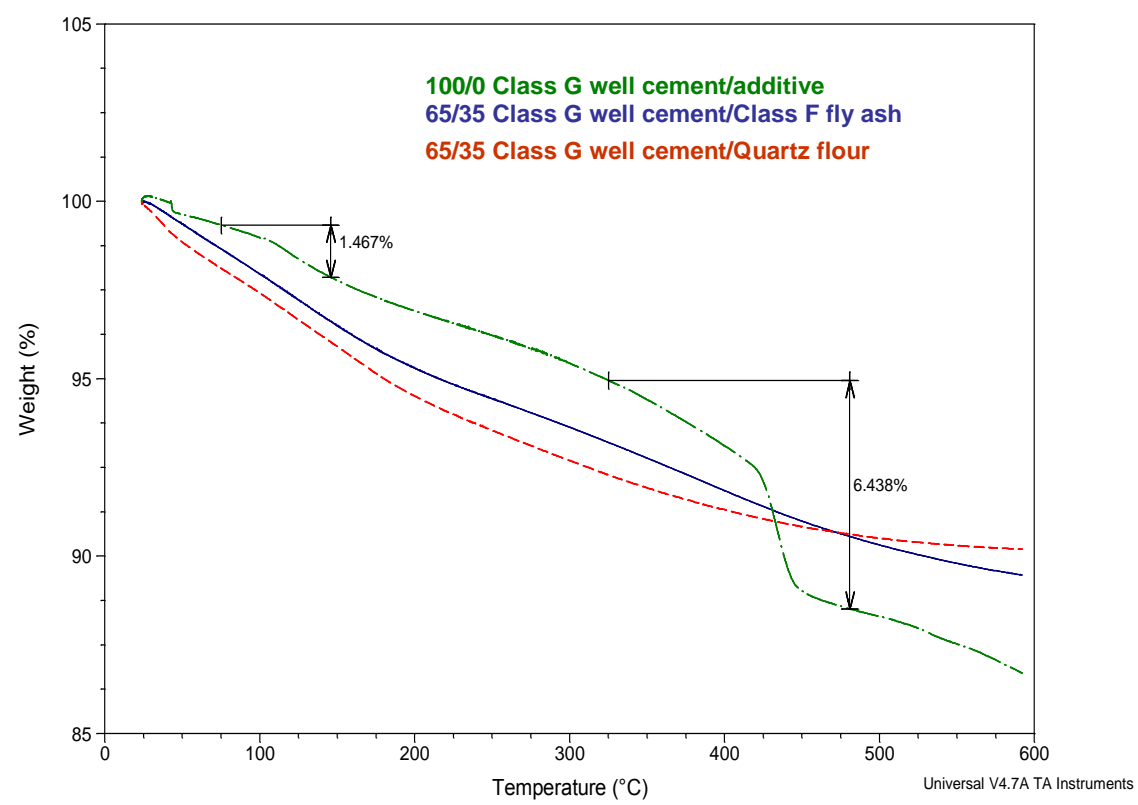

Figure 14. Non-isothermal TGA curves of the Class G cement, and the 65/35 Class $\mathrm{G} / \mathrm{Class} \mathrm{F}$ fly ash and /quartz flour ratio cements after $200^{\circ} \mathrm{C}$ autoclaving. 


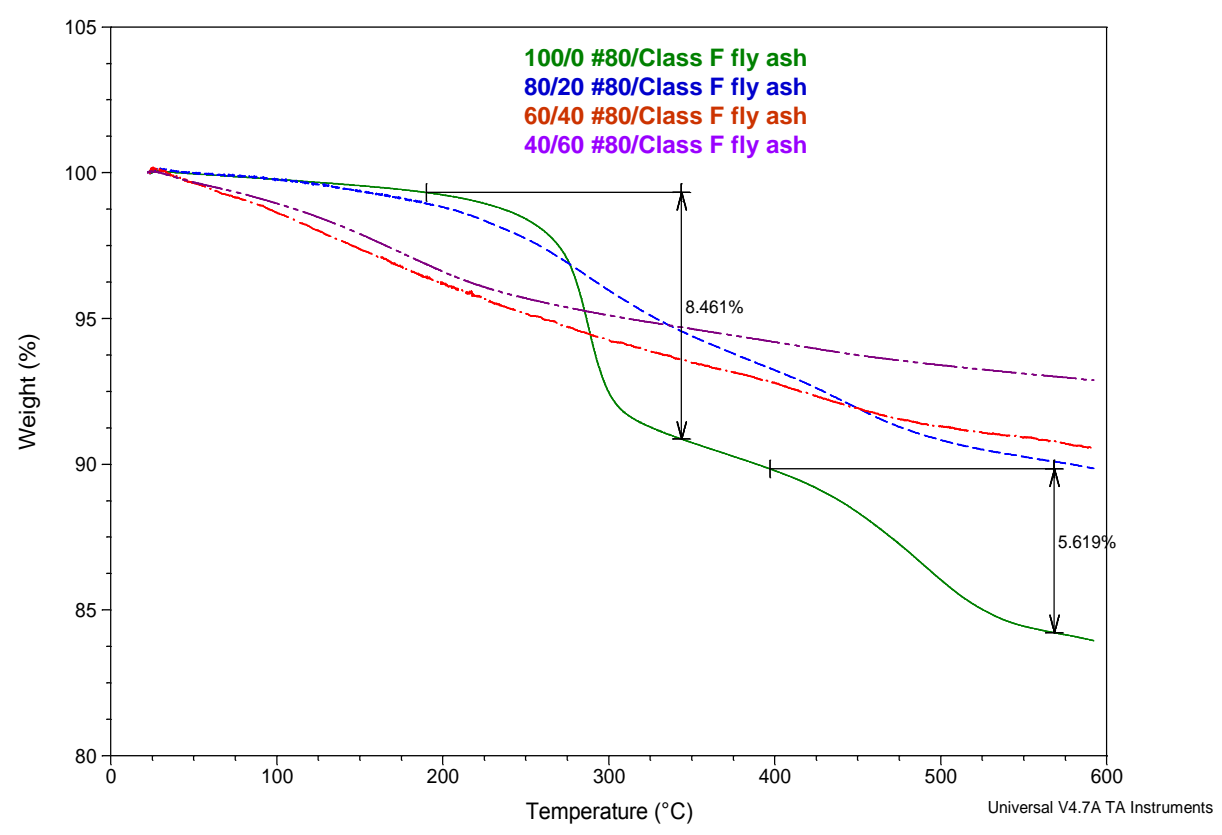

Figure 15. TGA curves for $200^{\circ} \mathrm{C}$-autoclaved 100/0, 80/20, 60/40, and 40/60 \#80/Class F fly ash ratio cements.

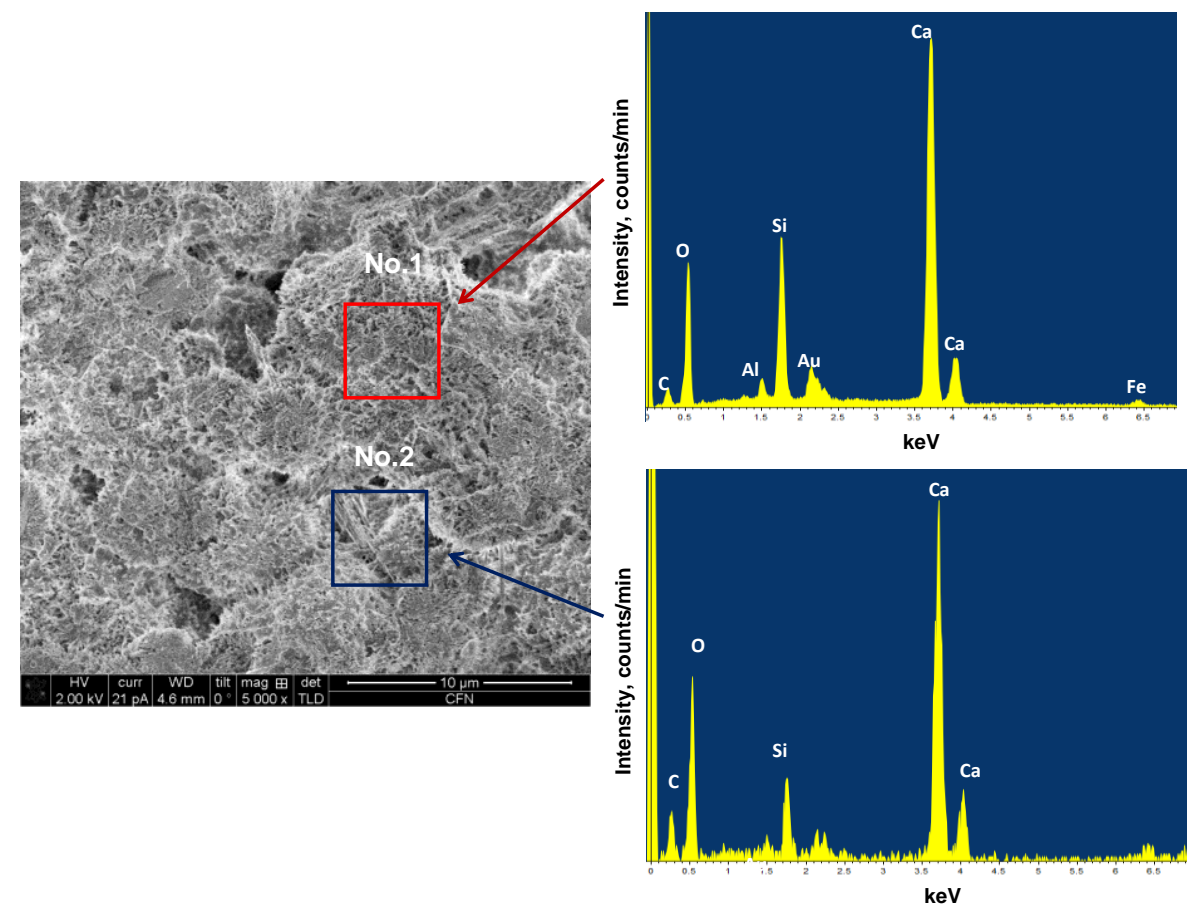

Figure 16. SEM micrographs coupled with EDX analyses for the fractured surface of $200^{\circ} \mathrm{C}$-autoclaved Class $\mathrm{G}$ cement. 


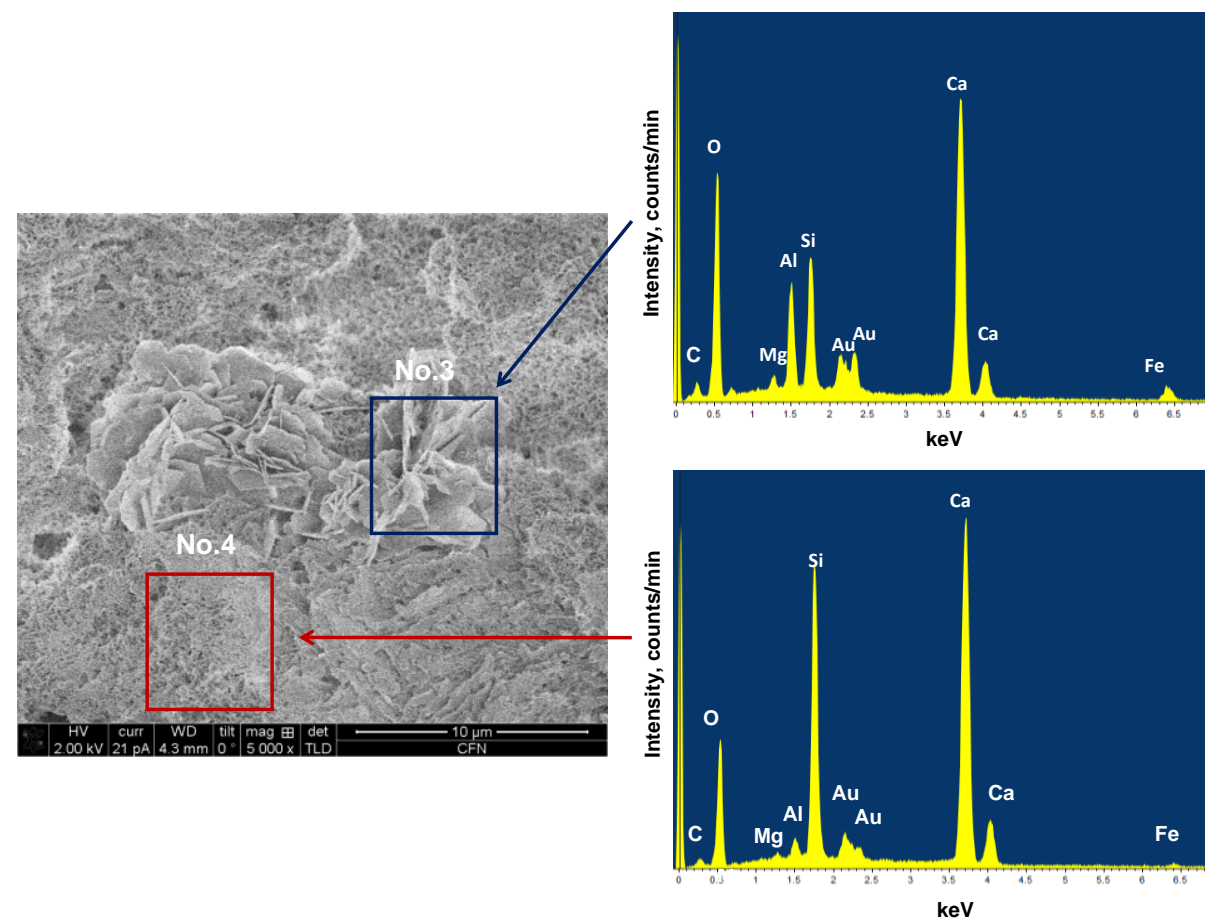

Figure 17. SEM image coupled with EDX analyses for the fractured surface of Class G cement after 1 cycle heat-water quenching test.

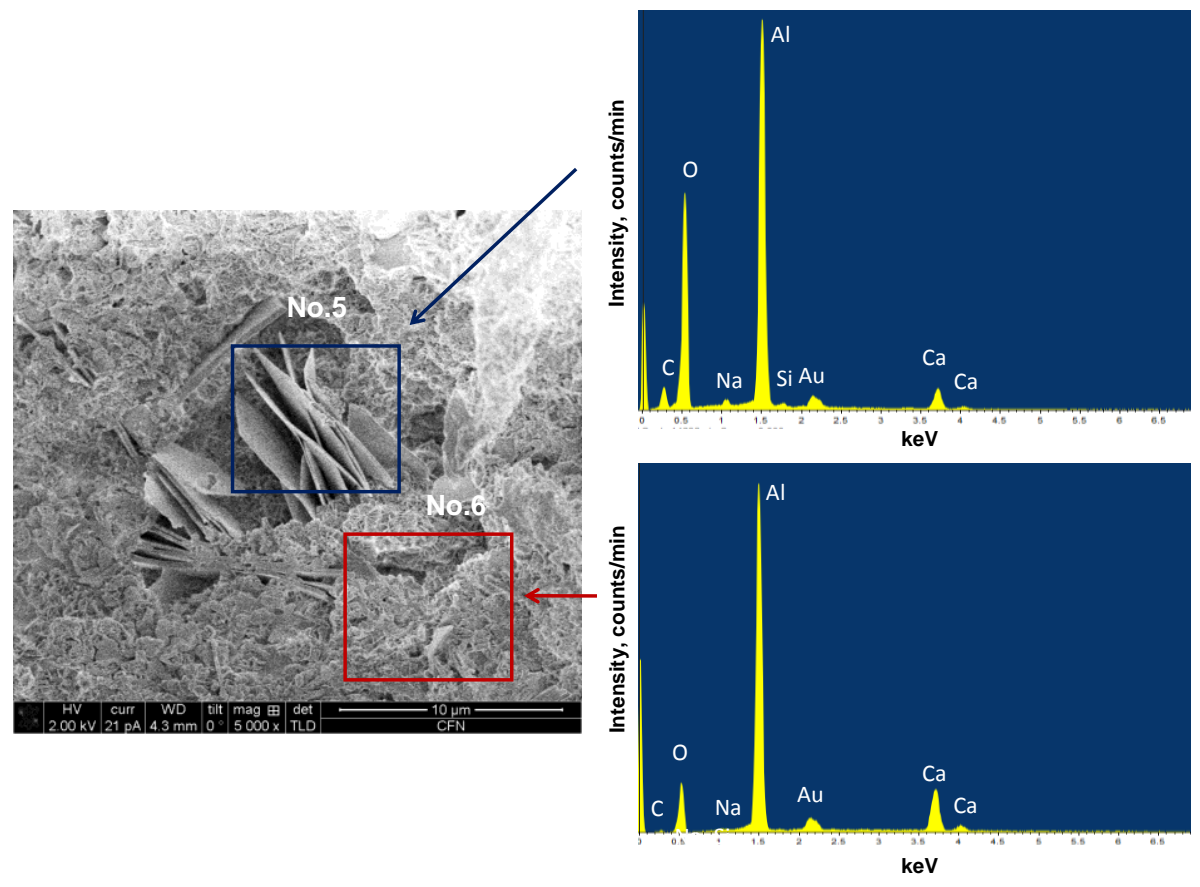

Figure 18. SEM-EDX analyses for the fractured surface of $200^{\circ} \mathrm{C}$-autoclaved \#80 cement. 


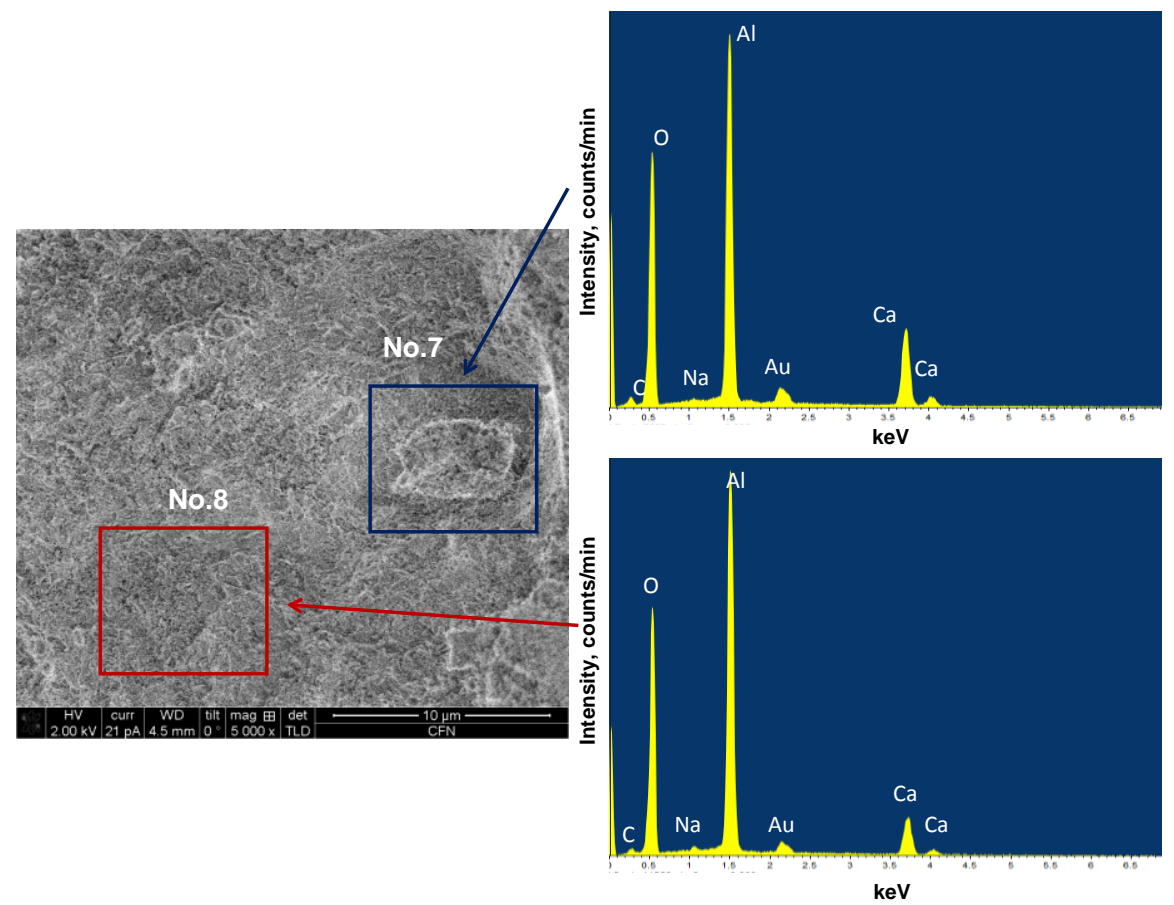

Figure 19. SEM-EDX exploration for the fractured surface of 5-cycle heat-water quenching test.

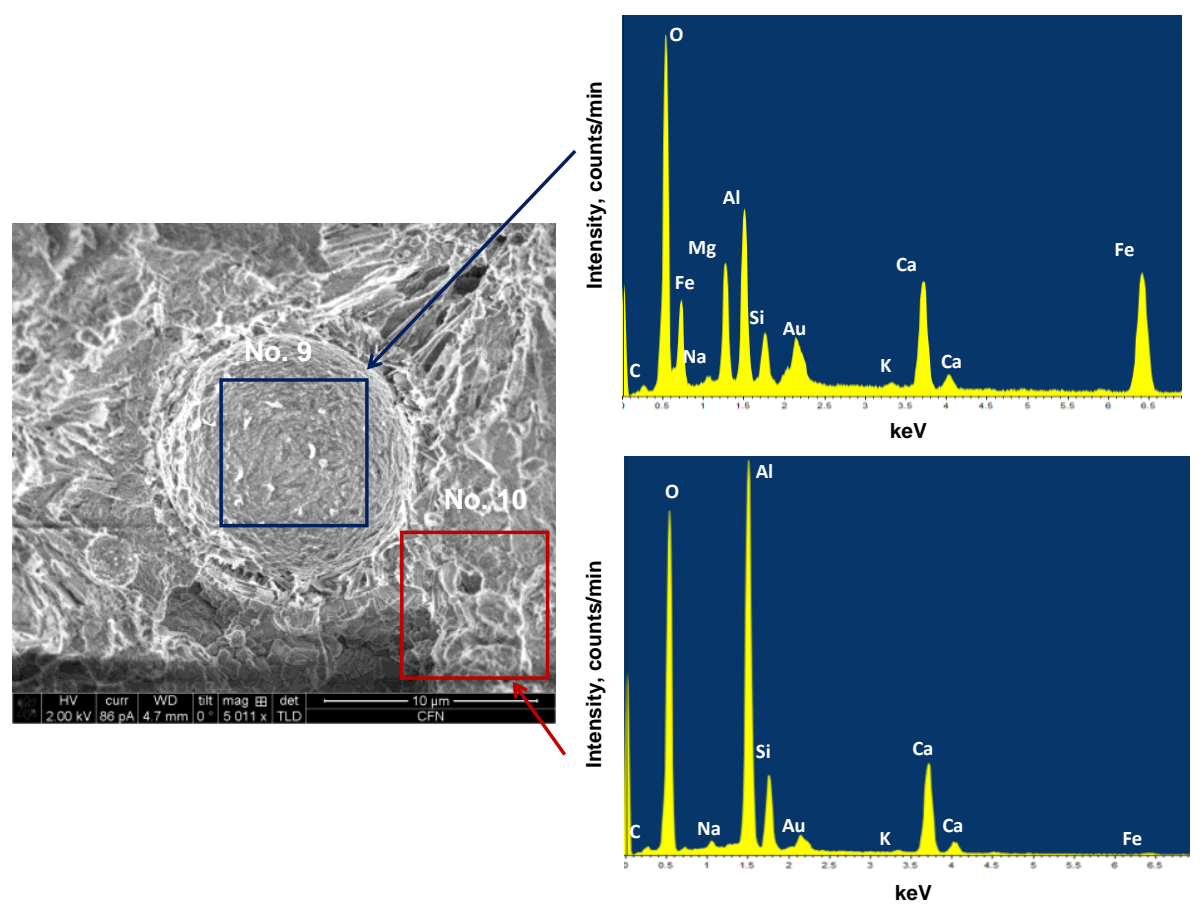

Figure 20. SEM-EDX exploration for the fractured surface of 60/40 \#80/Class F fly ash ratio cement after $200^{\circ} \mathrm{C}$ autoclaving. 


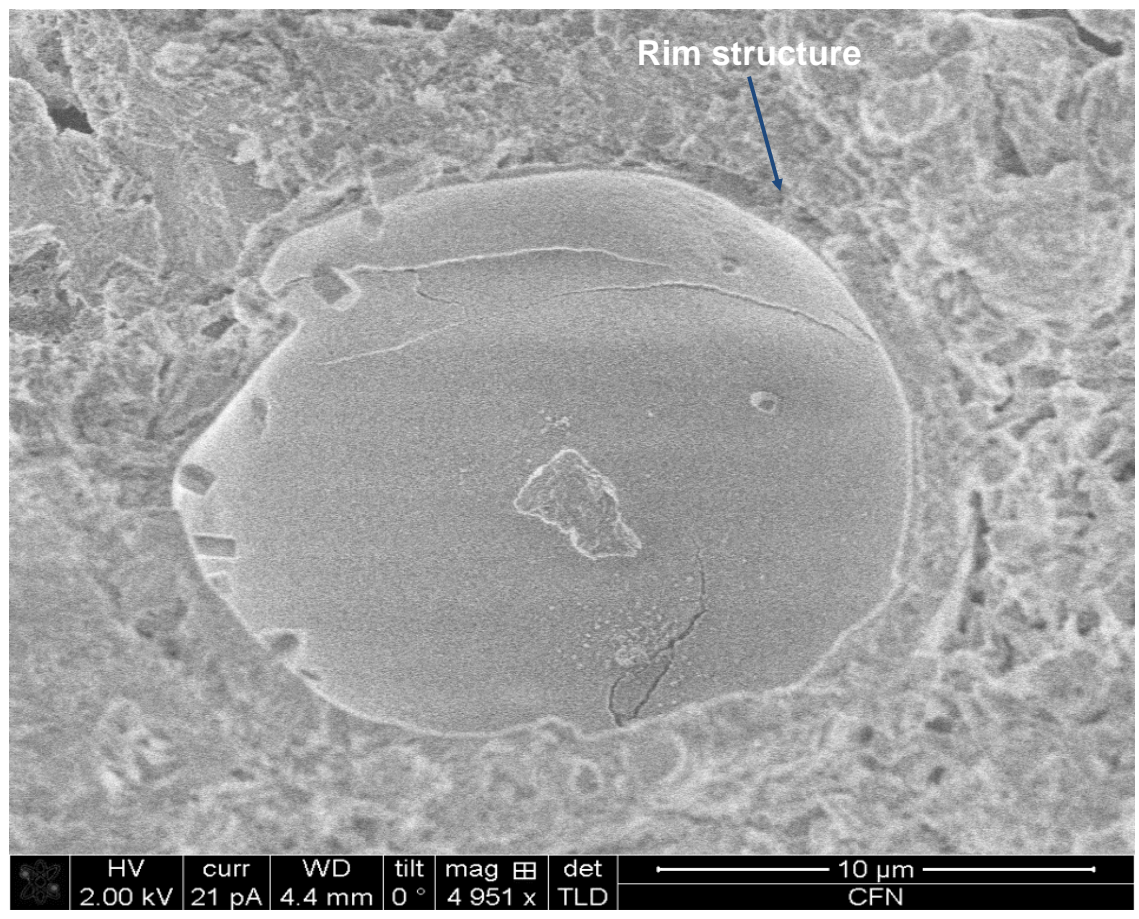

Figure 21. Very dense microstructure developed in the 60/40 \#80/Class F fly ash ratio cement after 5-cycle heat-water quenching test. 
